\title{
Cold Acclimation Attributes of Two Asparagus Cultivars with Varying Patterns of Fern Senescence
}

\author{
Erik J. Landry and David J. Wolyn ${ }^{1}$ \\ Department of Plant Agriculture, University of Guelph, Guelph, Ontario, Canada, N1G 2W1
}

\begin{abstract}
AdDitional INDEX wORDs. freezing tolerance, carbohydrates, nitrogen, Asparagus officinalis, dehydration, proline
Abstract. Adequate winterhardiness is crucial for yield stability of asparagus (Asparagus officinalis) cultivars in southern Ontario, Canada, and could be influenced by pattern of the fall fern senescence. Fern of cultivar Guelph Millennium (GM) turns yellow or senesces by mid-October, before that of cultivar Jersey Giant (JG), which often remains green until a killing frost. Early fern senescence could be a signal for cold acclimation competency and consequently winterhardiness, explaining the superior stand longevity and yield observed for GM compared with JG. A field experiment was conducted from mid-August to November to measure physiological parameters related to cold acclimation in fern, rhizome, and storage roots. During fall, fern chlorophyll concentration, rhizome nitrogen concentration, percent water of the crown, and storage root $\mathbf{L T}_{50}$ (temperature at which $50 \%$ cell death occurs) decreased. Cultivars did not differ for storage root percent water; however, values were smaller (greater dehydration) for GM than JG in the rhizome. At the end of the sampling period, GM had higher and lower concentrations of rhizome low-molecular-weight, non-structural carbohydrates and sucrose, respectively, than JG, which could support a hypothesis of greater winterhardiness in GM. Storage root $\mathrm{LT}_{50}$ values of $-19{ }^{\circ} \mathrm{C}$ and the lack of cultivar differences for this trait, in conjunction with differences between GM and JG for rhizome traits thought to be important for freezing tolerance, suggest characteristics of the rhizome in conjunction with timing of fern senescence may be important in cold acclimation of asparagus.
\end{abstract}

Asparagus is an herbaceous perennial in which the aboveground fern senesces, turning yellow in the fall, leaving the crown to overwinter. In southern Ontario, the primary production region within Canada, winter temperatures below $-20{ }^{\circ} \mathrm{C}$, early-October frosts, and winter freeze-thaw cycles are possible, requiring adapted germplasm for these conditions.

The predominant cultivars grown in southern Ontario, GM and JG, show contrasting patterns of fall fern senescence. The fern of GM is earlier to yellow than that of JG, which will often freeze while still green. GM yields more and has greater longevity than JG, which is often observed to decline, showing decreased yields and increased plant mortality over time, which could be attributable to any number of stress factors, including pathogens, allelopathy (Hartung and Stephens, 1983) and/or winterhardiness.

The freezing of non-senescent fern could contribute to decline, because removal of green fern from actively growing asparagus has been shown to have a negative impact on yield (Bai and Kelly, 1999). Nitrogen remobilization from photosynthetic tissues to overwintering storage organs could be limited because $90 \%$ of fern nitrogen translocates to the crown during senescence (Ledgard et al., 1994).

Short daylength has been implicated as a key developmental signal controlling growth and the partitioning of assimilates into the asparagus crown (Guo et al., 2002; Wooley et al., 1999). Crown carbohydrate accumulation induced by short daylength, an increase of root:shoot ratio (Woolley et al., 2002), and a reduction in sink capacity (Thomas and Stoddart, 1980) may promote senescence.

Received for publication 5 Jan. 2011. Accepted for publication 28 Mar. 2011. Funding was provided by the Ontario Asparagus Growers' Marketing Board and the Natural Science and Engineering Research Council of Canada and the Ontario Ministry of Agriculture, Food and Rural Affairs.

${ }^{1}$ Corresponding author. E-mail: dwolyn@uoguelph.ca.
The initiation of cold acclimation and extent of winterhardiness can also be influenced by the onset of senescence (Guy, 2003; Levitt, 1980). Late fall vegetative growth has been shown to negatively correlate with yield in asparagus (Bai and Kelly, 1999) as well as winterhardiness and yield in alfalfa (Medicago sativa) (Dhont, 2006). Because asparagus is herbaceous, the "stay green" phenotype characteristic of JG in southern Ontario could predispose this cultivar to deficiencies in cold acclimation, freezing tolerance, and consequently longevity.

The phenology of cold acclimation for asparagus (Krug, 1999) like many herbaceous perennials (Sakai and Larcher, 1987; Xin and Browse, 2000) can be categorized into two stages. The first is initiated by short days and daily temperatures ranging from 10 to $20^{\circ} \mathrm{C}$. During this period, the overwintering organs dehydrate and accumulate carbohydrate (Stout, 1980), leading to an increase of abscisic acid (Bressan et al., 2006) and proline concentrations (Singh et al., 1972; Tatar and Gevrek, 2008) and finally freezing tolerance (Kacperska-Palacz, 1978). During the second stage at temperatures near or below $0{ }^{\circ} \mathrm{C}$, freezing tolerance increases further and often is correlated with increased osmolytes, changes in fructan isomerization, and soluble protein and unsaturated plasma membrane phospholipid concentrations (Livingston, 1996; Patton et al., 2007a, 2007b).

Compounds such as proline, simple sugars, certain proteins, and oligosaccharides such as raffinose and fructan (Alden and Hermann, 1971) are osmolites with cryoprotective properties. Proline has been implicated as a protein stabilizer during water stress and mediates the loss of osmotic responsiveness resulting from dehydration (Heber et al., 1971; Steponkus, 1984). Sucrose has been shown to specifically substitute for water as intercellular ice forms (Caffrey et al., 1988; Thebud and Santarius, 1982). Raffinose can prevent sucrose from crystallizing at extreme low temperatures (Caffrey et al., 1988) and 
has been associated with winterhardiness, even at low concentrations (Ashworth et al., 1993; Hincha et al., 2007). Stressinduced proteins, dehydrins, have a stabilizing effect on sugars by increasing the average strength of hydrogen bonding (Trischuk et al., 2006). Fructans of various size classes can interact with membranes, limiting phase transitions and fusion as a result of dehydration (Hincha et al., 2007).

Asparagus only produces fructan within the crown, which can account for up to $90 \%$ of the total root carbohydrates (Cairns, 1992). Oligo- (low-molecular-weight) and poly- (highmolecular-weight) fructooligosaccharides have degrees of polymerization (DP) of 10 DP or less and greater than 10 fructose moieties attached to a glucose monomer, respectively (Norio et al., 2007). Asparagus storage root fructan averages between 13 and 16 DP, but this factor can vary with the genotype, time of year, and the presence of abiotic and biotic stress factors (Norio et al., 2007; Pressman et al., 1989; Shiomi, 1992).

Hydrolysis of fructan results in the production of simple sugars (Gasecka et al., 2008; Taga et al., 1980). In Israel, where winters are mild, fructans in asparagus crowns declined and sucrose increased progressively during fall senescence and winter dormancy. Although simple sugars, mainly sucrose, fructose, and glucose, are used for respiration and spring regrowth (Alden and Hermann, 1971; Norio et al., 2007; Pressman et al., 1993; Wilson et al., 2008), they could also act as cryoprotectants to increase freezing tolerance (Allison et al., 1999).

Few studies have measured the freezing tolerance or identified key cryoprotective metabolites of field-grown asparagus. Temperatures below $-30{ }^{\circ} \mathrm{C}$ without snow cover in Minnesota resulted in JG mortality (Fritz et al., 2005). In Japan, 1 -year-old crowns of cultivar Mary Washington grown under field conditions and harvested in December showed considerable freezing damage when exposed to controlled temperatures less than $-10{ }^{\circ} \mathrm{C}$ and complete death below $-15{ }^{\circ} \mathrm{C}$ (Imakawa and Harada, 1989). The accumulation of carbohydrates within the asparagus crown before dormancy has been linked to freezing tolerance and yield (Burrows et al., 1989; Pressman et al., 1989, 1993; Shelton and Lacy, 1980), but other cryoprotective compounds have not been investigated.

The distinct patterns of fall fern senescence and associated variation in longevity observed between GM and JG in southern Ontario could be related to differences in cold acclimation and ultimately freezing tolerance. The objective of this experiment was to study physiological parameters during the fall thought to be important for cold acclimation and identify cultivar differences that would then facilitate future experimentation that examines direct associations of traits with crown freezing tolerance, leading to the identification of indirect measures that could be used to breed for winterhardiness.

\section{Materials and Methods}

Establishment. Field trials were conducted at the University of Guelph Simcoe Research Station, Simcoe, Ontario, Canada (lat. $42^{\circ} 51^{\prime} \mathrm{N}$, long. $80^{\circ} 16^{\prime} \mathrm{W}$, elevation $240.5 \mathrm{~m}$ ). Commercially available 1-year-old asparagus crowns of JG and GM were transplanted into 20-cm-deep trenches on 6 May 2008 and 2009. The crowns were covered with $5 \mathrm{~cm}$ of soil and the trenches were gradually filled during the summer.

The experiment was conducted as a balanced split-plot design with cultivars as sub-plots and sampling dates as main plots. Main plots were organized using a randomized complete- block design with two blocks at each of two research station locations. Location one was a Scotland Sand (Brunisolic Grey Brown Luvisol) and location two was a Tavistock Loam (Gleyed Brunisolic Grey Brown Luvisol). The six main plots were sampled in 2008 on 15 Aug., 15 Sept., 1 Oct., 20 Oct., and 3 Nov., whereas in 2009, samples were taken on 18 Aug., 14 Sept., 28 Sept., 14 Oct., and 16 Nov. Similar sampling dates were combined over the 2 years to create five generalized sampling dates: mid-August (15 and 18 Aug.), mid-September (14 and 15 Sept.), early October (28 Sept. and 1 Oct.), midOctober (14 and 20 Oct.), and November (3 and 16 Nov.). Subplots consisted of 10 crowns spaced $20 \mathrm{~cm}$ within a row. Two additional border plants were planted at the ends of each row and rows were spaced $1.5 \mathrm{~m}$ apart. Guard rows separated each of the main plots.

All crowns were fertilized $\left(50 \mathrm{~kg} \cdot \mathrm{ha}^{-1} 10 \mathrm{~N}-4.4 \mathrm{P}-8.3 \mathrm{~K}\right)$ in May, June, and July of both years. Manual weed removal and interrow applications of glyphosate $\left(360 \mathrm{~g} \cdot \mathrm{L}^{-1}\right)$ (Monsanto, St. Louis, MO) were used as needed.

Fall harvest TREatments. On each of the sampling dates, 10 plants from each sub-plot were dug from the field during the morning, cleaned of soil, separated into aboveground fern and belowground crown material, and stored in burlap bags at $6{ }^{\circ} \mathrm{C}$ until further treatment. Of the 10 harvested plants, five were processed for fresh weight (FW), dry weight (DW), and water content, whereas the remaining five were processed for freezing assessment and metabolite analysis. Whole crowns were dried for 2 weeks at $80{ }^{\circ} \mathrm{C}$. Water content (\%) was determined as $[(\mathrm{FW}-\mathrm{DW} / \mathrm{FW})] \times 100$ (Tanino et al., 1990). Total crown DW and crown water were only presented for 2009 data, because 2008 samples were dried inadequately.

Chlorophyll concentration was quantified using five randomly selected mature ferns per sub-plot. Cladophylls, $500 \mathrm{mg}$ FW, were randomly sampled from each fern and combined into one $30 \times 115-\mathrm{mm}, 50-\mathrm{mL}$ polypropylene conical tube for a total of five sub-samples per sub-plot. Tissue from each sub-sample was extracted with $25 \mathrm{~mL} 99 \% \mathrm{CH}_{3} \mathrm{OH}$ at $65^{\circ} \mathrm{C}$ for $10 \mathrm{~min}$ then stored at $4{ }^{\circ} \mathrm{C}$ overnight. After centrifugation at $2000 g_{n}$ for 10 min, $3 \mathrm{~mL}$ of the supernatant was recovered and transferred into a standard polystyrene cuvette (10-mm light path) and measured at both $665 \mathrm{~nm}$ and $652 \mathrm{~nm}$ using a spectrophotometer (Ultraspec 2100 pro ultraviolet/Visible; Biochrom, Cambridge, UK). Total chlorophyll was calculated according to Lichtenthaler (1987): micrograms total chlorophyll per milliliter of extract $=$ $(1.44)\left(\mathrm{A}_{665 \mathrm{~nm}}\right)+(24.93)\left(\mathrm{A}_{652 \mathrm{~nm}}\right)$.

Freezing treatment. To quantify freezing tolerance, storage root tissues, $\approx 5 \mathrm{~cm}$ in length, within $10 \mathrm{~cm}$ from the rhizome, were frozen at predetermined temperatures and assessed for electrolyte leakage for each sampling date as follows. Randomly sampled storage roots, 160 per sub-plot, were individually placed into glass test tubes $(25 \times 150 \mathrm{~mm})$ and distributed into eight 40-cell test tube racks, where each rack contained 20 tubes of each cultivar. Within a rack, tubes for each cultivar were grouped together. Seven of the eight racks were placed into a household chest freezer (Woods, Guelph, Ontario, Canada). The remaining rack from each block was held at $4{ }^{\circ} \mathrm{C}$ for $48 \mathrm{~h}$ and served as a control. Separate freezers were used for each of the four replicate blocks corresponding to the two replications $\times$ two locations in the field. Freezers were maintained at $4{ }^{\circ} \mathrm{C}$ for $2 \mathrm{~h}$ then at $-3{ }^{\circ} \mathrm{C}$ for $12 \mathrm{~h}$ to allow ice nucleation. Additional freezing treatments of $-6,-9,-12,-15$, and $-18{ }^{\circ} \mathrm{C}$ were achieved by decreasing the 
temperature by $3{ }^{\circ} \mathrm{C}$ per hour and then holding the temperature for $1 \mathrm{~h}$. A thermocouple (HOBO; Onset Computer, Pocasset, MA) was used to monitor and verify temperature treatments. One rack was removed from each freezer once each temperature was maintained for the designated period and then incubated at $4{ }^{\circ} \mathrm{C}$ for $12 \mathrm{~h}$. To each tube, $25 \mathrm{~mL}$ of $\mathrm{dH}_{2} \mathrm{O}$ was added and all racks were placed on a rotary shaker $(400 \mathrm{rpm})$ for $24 \mathrm{~h}$ at room temperature. The resulting solutions were measured for electrical conductivity (EC) with a Hanna instruments pH/conductivity meter (H19810; Caprock Developments, Morris Plains, NJ). Once the initial conductivity measurements were made, samples were autoclaved (20 min at $121^{\circ} \mathrm{C}$ and $0.138 \mathrm{MPa}$ ), incubated for $24 \mathrm{~h}$ on a rotary shaker (400 rpm), and measured again for EC. Relative electrolyte leakage (REL) was determined by the equation: (conductivity once autoclaved/conductivity post-freezing) $\times 100$ (Zatylny et al., 1996).

The sigmoidal curve fitting function PROC NLIN (SAS Version 9.1; SAS Institute, Cary, NC) was used to estimate $\mathrm{LT}_{50}$ values according to Patton and Reicher (2007): survival $=$ $\mathrm{Y}_{\min }+\left(\mathrm{Y}_{\max }-\mathrm{Y}_{\min }\right) /\left\{1+\left[e^{\mathrm{k}(\mathrm{Tm}-\mathrm{T})}\right]\right\}$ where $\mathrm{Y}_{\min }=$ lower bound of REL, $Y_{\text {max }}=$ upper bound of REL, $e^{\mathrm{k}}=$ inflection point slope function, $\mathrm{Tm}=$ temperature at the inflection point $\left(\mathrm{LT}_{50}\right), \mathrm{K}=$ function estimation of the slope, and $\mathrm{T}=$ treatment temperature. PROC NLIN estimates Tm, the temperature representing the inflection point, or $\mathrm{LT}_{50}$, the value representing the temperature at which $50 \%$ cell death occurs, equated in this experiment to $50 \%$ ion leakage.

Metabolite anAlysis. Five to 10 random storage roots from each crown (within $10 \mathrm{~cm}$ of the rhizome) were bulked, weighed $(\approx 10$ to $15 \mathrm{~g} \mathrm{FW})$, and placed into $50-\mathrm{mL}$ polypropylene conical tubes. The rhizome from each crown was excised of bud scales and epidermal tissue and then placed in a $30 \times 115-\mathrm{mm}, 50-\mathrm{mL}$ polypropylene conical tube. Tissue was frozen in liquid nitrogen, lyophilized (Model 77510; Labconco, Kansas City, MO), and weighed to determine DW. Water content (\%) was calculated as previously described. Samples were ground with a mortar and pestle to pass a 60 -mesh sieve and then stored at $-80{ }^{\circ} \mathrm{C}$ (Model 923; Forma Scientific, Marretta, $\mathrm{OH})$ until further use.

Total nitrogen (\%) was assessed using a nitrogen analyzer (Model FP-428; Leco, St. Joseph, MI). Samples ( $\approx 50$ mg DW) were combusted in a sealed system, resulting in the release of nitrogen compounds; after reduction to $\mathrm{N}_{2}$ gas, the total nitrogen was measured by the thermal conductivity cell.

Protein was quantified using the Bio-Rad Protein Assay procedure (Bio-Rad Laboratories, Mississauga, Ontario, Canada) based on the method of Bradford (1976). Soluble protein was extracted from $100 \mathrm{mg}$ DW storage root or $50 \mathrm{mg}$ DW rhizome tissue with $1 \mathrm{~mL}$ extraction buffer $(0.1 \mathrm{M}$ Tris, $150 \mathrm{~mm}$ $\mathrm{NaCl}, 0.1 \%$ Tween 20, pH 8.0). The supernatant was decanted once centrifuged at $5000 g_{n}$ for $10 \mathrm{~min}$. To the supernatant, $1 \mathrm{~mL}$ of cold protein precipitation solution [10\% (w/v) TCA, $90 \%(\mathrm{v} / \mathrm{v})$ $\left(\mathrm{CH}_{3}\right)_{2} \mathrm{CO}, 0.1 \% \beta$-mercaptoethanol] kept at $-20{ }^{\circ} \mathrm{C}$ was added. Thereafter, the solutions were incubated at $-20{ }^{\circ} \mathrm{C}$ for $1 \mathrm{~h}$ and then centrifuged at $12,000 g_{n}$ for $10 \mathrm{~min}$ at $5{ }^{\circ} \mathrm{C}$. The pellet was washed with two cycles of vortexing with $1 \mathrm{~mL}$ of $100 \%$ $\left(\mathrm{CH}_{3}\right)_{2} \mathrm{CO}$ solution and centrifugation at $12,000 \mathrm{~g}_{n}$ for $10 \mathrm{~min}$ at $5{ }^{\circ} \mathrm{C}$. The resulting pellet was allowed to dry overnight and then resolubilized in $1 \mathrm{~mL}$ of $0.1 \mathrm{M} \mathrm{NaOH}$. Triplicate $100-\mu \mathrm{L}$ samples of extract were assayed with $5 \mathrm{~mL}$ of 1:4 diluted Bradford dye reagent $[0.004 \%(\mathrm{v} / \mathrm{v})$ Brilliant blue $\mathrm{G}, 10 \%(\mathrm{v} / \mathrm{v})$ phosphoric acid, 4\% $\mathrm{CH}_{3} \mathrm{OH}: \mathrm{dH}_{2} \mathrm{O}$ ] and the solution was measured at $595 \mathrm{~nm}$ with a spectrophotometer (Ultraspec 2100 pro ultraviolet/Visible). Protein was estimated as $\mathrm{mg} \cdot \mathrm{g}^{-1} \mathrm{DW}$ according to a 0.9 to $2 \mathrm{mg} \cdot \mathrm{mL}^{-1}$ bovine serum albumin standard curve.

Proline was assayed using acid ninhydrin as described by Patton et al. (2007b). Briefly, $30 \mathrm{mg}$ DW of ground storage root or rhizome was homogenized with $1 \mathrm{~mL}$ of EtOH solution [3\% $(\mathrm{w} / \mathrm{v})$ sulfosalicylic acid in $80 \%(\mathrm{v} / \mathrm{v}) \mathrm{EtOH}$ in $2-\mathrm{mL}$ microcentrifuge tubes. Samples were incubated for $20 \mathrm{~min}$ at $70^{\circ} \mathrm{C}$, removed, and cooled on an orbital shaker $(150 \mathrm{rpm})$ for $15 \mathrm{~min}$. Once cooled, samples were centrifuged at $16,000 \mathrm{~g}_{n}$ for $10 \mathrm{~min}$ at room temperature and the pellet was washed twice with EtOH solution by two additional repetitions of vortexing and centrifugation. Aliquots of $100 \mu \mathrm{L}$ were transferred into $13 \mathrm{~mm}$, 20-mL borosilicate glass test tubes containing $1 \mathrm{~mL}$ of acid ninhydrin (1.25 g ninhydrin in $30 \mathrm{~mL}$ glacial acetic acid, 13.8

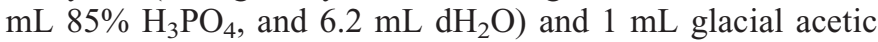
acid. Tubes were vortexed for $15 \mathrm{~s}$ and placed in a $90{ }^{\circ} \mathrm{C}$ water bath for $1 \mathrm{~h}$. The reaction was stopped by placing the tubes in an ice bath. To extract the chromophore, $4 \mathrm{~mL}$ of toluene was added to the tube; the tube was further vortexed for $15 \mathrm{~s}$, and aqueous and non-aqueous phases were allowed to separate. Two milliliters of the upper non-aqueous phase, containing the chromophore, was pipetted into a quartz cuvette and measured for absorbance at $520 \mathrm{~nm}$ with a spectrophotometer (DU-64; Beckman, Fullerton, CA). Proline concentration was estimated as milligrams per gram DW using a 0 to $60 \mu \mathrm{g} \cdot \mathrm{mg}^{-1} \mathrm{~L}$ proline standard curve.

Total non-structural carbohydrates (TNC) (reducing and non-reducing sugars) were quantified with the anthrone method (Yemm and Willis, 1954). Briefly, soluble sugars were extracted from 250-mg DW storage root or 500-mg DW rhizome tissue samples and separated sequentially with 90\% (v/v) EtOH and $\mathrm{dH}_{2} \mathrm{O}$ solutions into low-molecular-weight and highmolecular-weight carbohydrates, respectively (Grotelueschen and Smith, 1968; Livingston, 1990). Endogenous enzymes were first inactivated by incubation of the tissue with $3 \mathrm{~mL}$ of $90 \%$ (v/v) EtOH at $70^{\circ} \mathrm{C}$ for $10 \mathrm{~min}$. After centrifugation for 10 min at $3000 g_{n}$, the supernatant was saved and the pellet extracted twice more with $3 \mathrm{~mL}$ of $90 \%$ (v/v) EtOH at $40{ }^{\circ} \mathrm{C}$ for $10 \mathrm{~min}$. Once the sample was extracted with $\mathrm{EtOH}$, a white precipitate was observed as a surface layer on the remaining pellet. The supernatants from the three EtOH extractions were pooled and brought up to a $10-\mathrm{mL}$ volume with $90 \%(\mathrm{v} / \mathrm{v})$ EtOH. To extract the residual carbohydrates, the remaining pellet was incubated with $4 \mathrm{~mL}$ of $\mathrm{dH}_{2} \mathrm{O}$ at $80{ }^{\circ} \mathrm{C}$ for $15 \mathrm{~min}$; after centrifugation for $10 \mathrm{~min}$ at $3000 \mathrm{~g}_{n}$, the extraction was repeated. The two supernatants were pooled and brought up to a $10 \mathrm{~mL}$ volume with $\mathrm{dH}_{2} \mathrm{O}$.

To detect carbohydrates with the anthrone method, $100 \mu \mathrm{L}$ of extract was added to $3 \mathrm{~mL}$ of anthrone solution $[72 \%(\mathrm{v} / \mathrm{v})$ $\mathrm{H}_{2} \mathrm{SO}_{4}+15 \%(\mathrm{w} / \mathrm{v})$ anthrone]. After $11 \mathrm{~min}$ of boiling at $100{ }^{\circ} \mathrm{C}$, the samples were cooled on ice and measured for absorbance at $625 \mathrm{~nm}$ (Ultraspec 2100 pro ultraviolet/Visible spectrophotometer). TNC concentrations were estimated as milligrams per gram DW using a 0 to $200 \mu \mathrm{g} \cdot \mathrm{mg}^{-1}$ fructose standard curve. EtOH extractions were diluted, as necessary, to produce values within the standard curve limits.

Glucose, sucrose, and raffinose were quantified using a commercially available kit (K-RAFGL; Megazyme International Ireland, Bray, Ireland) (McCleary et al., 2006). Tissue (500 mg 
DW) was extracted with $5 \mathrm{~mL}$ of $80 \%$ (v/v) EtOH and diluted to $50 \mathrm{~mL}$ with sodium acetate buffer $(50 \mathrm{~mm}, \mathrm{pH} 4.5)$. From each extract, $200-\mu \mathrm{L}$ aliquots were added to each of three 13-mm (20 $\mathrm{mL}$ ) borosilicate glass test tubes labeled A, B, and C. Tube A was assayed for glucose, Tube B for sucrose once hydrolyzed to glucose and fructose with $200 \mu \mathrm{L}$ of supplied invertase, and Tube $\mathrm{C}$ for raffinose once digested with a $200-\mu \mathrm{L}$ mixture of supplied $\alpha$-galactosidase and invertase. Tubes A, B, and $\mathrm{C}$ were incubated at $50{ }^{\circ} \mathrm{C}$ for $20 \mathrm{~min}$ to allow enzymatic hydrolysis. Thereafter, $3 \mathrm{~mL}$ of supplied glucose oxidase/peroxide reagent was added to each tube, which was incubated further for $20 \mathrm{~min}$ at $50{ }^{\circ} \mathrm{C}$. Finally, the absorbance was determined at $510 \mathrm{~nm}$ with a spectrophotometer (Ultraspec 2100 pro ultraviolet/

Table 1 . Summary of significant fixed effects $P \leq 0.05$ as determined from the restricted maximum likelihood (REML) covariance parameter estimates for asparagus cultivars Jersey Giant and Guelph Millennium sampled across five fall dates from midAugust to mid-November and combined over two locations (two sites at the Simcoe Research Station, Simcoe, Ontario, Canada) and 2 years (2008 and 2009).

\begin{tabular}{|c|c|c|c|}
\hline Parameter $^{z}$ & Cultivar & $\begin{array}{c}\text { Sampling } \\
\text { date }\end{array}$ & $\begin{array}{c}\text { Cultivar } \times \\
\text { sampling } \\
\text { date } \\
\end{array}$ \\
\hline Chlorophyll & $*$ & $*$ & NS \\
\hline Fern dry weight & NS & NS & NS \\
\hline Storage root nitrogen $(\%)$ & NS & NS & NS \\
\hline Rhizome nitrogen (\%) & $*$ & $*$ & NS \\
\hline 2009 crown water $(\%)$ & * & $*$ & NS \\
\hline Storage root water $(\%)$ & NS & $*$ & NS \\
\hline Rhizome water (\%) & $*$ & $*$ & NS \\
\hline 2009 crown dry weight & $*$ & $*$ & $*$ \\
\hline LNC storage root & NS & $*$ & NS \\
\hline LNC rhizome & NS & NS & $*$ \\
\hline HNC storage root & NS & $*$ & NS \\
\hline HNC rhizome & NS & NS & NS \\
\hline TNC storage root & NS & NS & NS \\
\hline TNC rhizome & NS & NS & $*$ \\
\hline LF storage root & NS & $*$ & NS \\
\hline LF rhizome & NS & NS & NS \\
\hline HF storage root & NS & $*$ & NS \\
\hline HF rhizome & NS & NS & $*$ \\
\hline Total fructan storage root & NS & $*$ & NS \\
\hline Total fructan rhizome & NS & $*$ & NS \\
\hline Reducing sugar storage root & $*$ & NS & $*$ \\
\hline Reducing sugar rhizome & NS & NS & NS \\
\hline Sucrose storage root & $*$ & NS & NS \\
\hline Sucrose rhizome & $*$ & $*$ & $*$ \\
\hline Raffinose rhizome & $*$ & $*$ & $*$ \\
\hline Glucose rhizome & NS & * & $*$ \\
\hline Proline storage root & $*$ & $*$ & $*$ \\
\hline Proline rhizome & NS & $*$ & NS \\
\hline Protein storage root & $*$ & $*$ & $*$ \\
\hline Protein rhizome & * & NS & NS \\
\hline $\mathrm{LT}_{50}$ & NS & $*$ & NS \\
\hline
\end{tabular}

$\overline{{ }^{2} \mathrm{TNC}}=$ total non-structural carbohydrates; LNC $=$ low-molecularweight, non-structural carbohydrates; $\mathrm{HNC}=$ high-molecular-weight, non-structural carbohydrates; LF = low-molecular-weight fructan; HF = high-molecular-weight fructan; $\mathrm{LT}_{50}=$ value representing the temperature at which $50 \%$ cell death occurs, as measured by $50 \%$ ion leakage.

*Significant; NS = non-significant.
Visible). This method measures the molarity of a sample using a control solution of glucose. The absorbance of Tube A was used to calculate the molarity of glucose, the difference in absorbance between $\mathrm{A}$ and $\mathrm{B}$ was used to calculate sucrose, and the difference between $\mathrm{C}$ and $\mathrm{B}$ was used to calculate raffinose according to supplied formulas. Glucose and sucrose were presented on a DW basis using their corresponding molecular weights, whereas raffinose content was calculated with the average molecular weight of the three raffinose-series oligosaccharides: raffinose, verbascose, and stachyose, because all are hydrolyzed with $\alpha$-galactosidase and invertase.

Low- and high-molecular-weight fructan was determined for storage root and rhizome tissues using a commercial fructan analysis kit (K-FRUC; Megazyme International Ireland) (McCleary et al., 1997). Tissue samples (100 mg DW storage root, $150 \mathrm{mg}$ DW rhizome) were extracted twice with $90 \%$ ETOH $(5 \mathrm{~mL})$ at $70{ }^{\circ} \mathrm{C}$ for $20 \mathrm{~min}$, centrifuged, decanted, and supernatant saved. The pellet was further extracted twice with

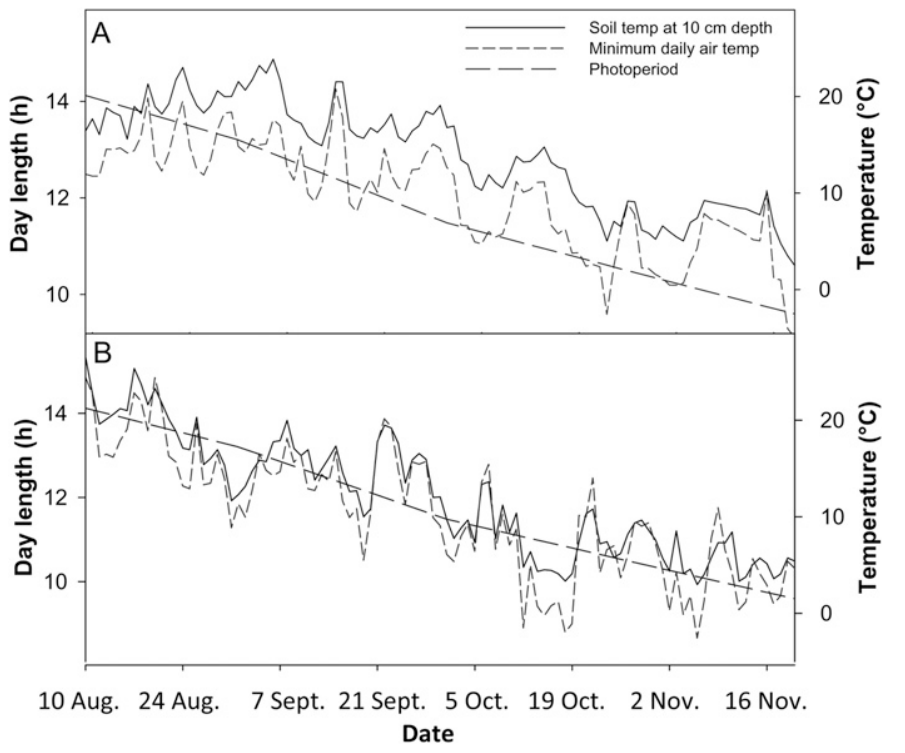

Fig. 1. Daylength and daily minimum air and soil temperatures at $5-\mathrm{cm}$ depth during the (A) 2008 and (B) 2009 fall seasons at the Simcoe Research Station, Simcoe, Ontario, Canada.

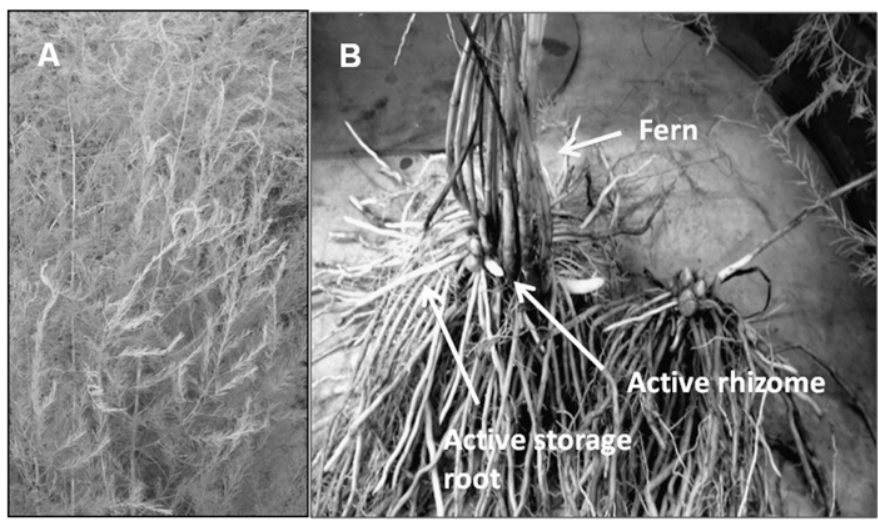

Fig. 2. (A) 'Jersey Giant' asparagus fern on 16 Nov. 2009 at Simcoe Research Station, Simcoe, Ontario, Canada. White cladophyll areas indicate frost damage. (B) 'Jersey Giant' (left) and 'Guelph Millennium' (right) asparagus crowns on 16 Nov. 2009 at Simcoe Research Station. 
$\mathrm{dH}_{2} \mathrm{O}(5 \mathrm{~mL})$ at $80^{\circ} \mathrm{C}$ for $20 \mathrm{~min}$, centrifuged, decanted, and supernatant saved. The high-molecular-weight, $\mathrm{dH}_{2} \mathrm{O}$ fraction, was adjusted to $80 \mathrm{~mL}$ with $\mathrm{dH}_{2} \mathrm{O}$, whereas the low-molecularweight, EtOH fraction, was evaporated to dryness and solubi-

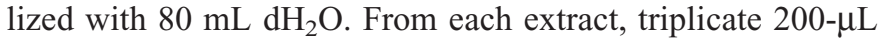
samples were incubated with $200 \mu \mathrm{L}$ of the supplied sucrase enzyme at $40{ }^{\circ} \mathrm{C}$ for $30 \mathrm{~min}$, whereas after, reducing sugars were removed with $200 \mu \mathrm{L}$ of alkaline borohydride solution during incubation at $40{ }^{\circ} \mathrm{C}$ for $30 \mathrm{~min}$. Thereafter, the $\mathrm{pH}$ was adjusted with $0.5 \mathrm{~mL}$ of acetic acid $(0.2 \mathrm{M})$. Fructan was hydrolyzed by adding $0.1 \mathrm{~mL}$ of fructanase solution to $0.2 \mathrm{~mL}$ of extract and incubation at $40{ }^{\circ} \mathrm{C}$ for $20 \mathrm{~min}$. The D-fructose and D-glucose produced were measured at $410 \mathrm{~nm}$ with a spectrophotometer (Ultraspec 2100 pro ultraviolet/Visible spectrophotometer) after incubation with $5 \mathrm{~mL}$ parahydroxybenzoic acid hydrazide (PAHBAH) at $100^{\circ} \mathrm{C}$ for $6 \mathrm{~min}$.

Reducing sugars were quantified using $200-\mu \mathrm{L}$ sub-samples of the fructan extract, before the addition of sucrase, mixed with $3 \mathrm{~mL}$ of PAHBAH at $100^{\circ} \mathrm{C}$ for $6 \mathrm{~min}$. Fructan and reducing sugars were estimated as milligrams per gram DW according to given formulas, which use a D-fructose control absorbance and conversion factors to measure free D-fructose or to convert Dfructose into fructan.

Statistical analysis. The restricted maximum likelihood covariance parameter estimates of Proc Mixed were used to analyze physiological parameters (SAS Version 9.1; SAS Institute). Standard errors of the mean were calculated depending on the significance of random and fixed effects. Nonpairwise comparisons are shown for significant cultivar and sample date interaction effects. If a parameter did not have a significant interaction effect but the effect of cultivar was significant, then pairwise comparisons of cultivars and cultivar least square means are presented. If the effect of cultivar or the interaction between cultivar and sample date was not significant but sampling date was significant, then cultivars were pooled. If sample date, cultivar, or their interaction was not significant, then cultivars were pooled unless stated otherwise. Significantly different means were separated according to Tukey's honestly significant difference using a $P \leq 0.05$. Dependent variables were tested for normality with the Shapiro-Wilk statistic. Chlorophyll was transformed using the exponential function $e^{\mathrm{x}}$. Storage root reducing sugar and rhizome glucose, raffinose, and proline concentrations were squareroot transformed. Untransformed data are presented in the figures.

Spearman's rank-order correlation coefficients, $r$, between $\mathrm{LT}_{50}$ and physiological or metabolic parameters were calculated using PROC CORR (SAS Version 9.1). Statistical significance was determined according to $P \leq 0.05$.

\section{Results}

Statistical analyses. The random effects of year, location, year $\times$ location, and their interactions with cultivar or sample date were not significant for each parameter; therefore, data were pooled over years and locations. The statistical significance of fixed effects, cultivar and sample date, and their interaction are summarized for all parameters (Table 1).

Fern Senescence And nitrogen. During early-Oct. 2008 (Fig. 1A) and 2009 (Fig. 1B), the Simcoe Research Station in Simcoe, Ontario, Canada, consistently experienced daily minimum air temperatures below $10{ }^{\circ} \mathrm{C}$ with photoperiod decreasing below $12 \mathrm{~h}$. The 2009 fall season was cool and wet compared

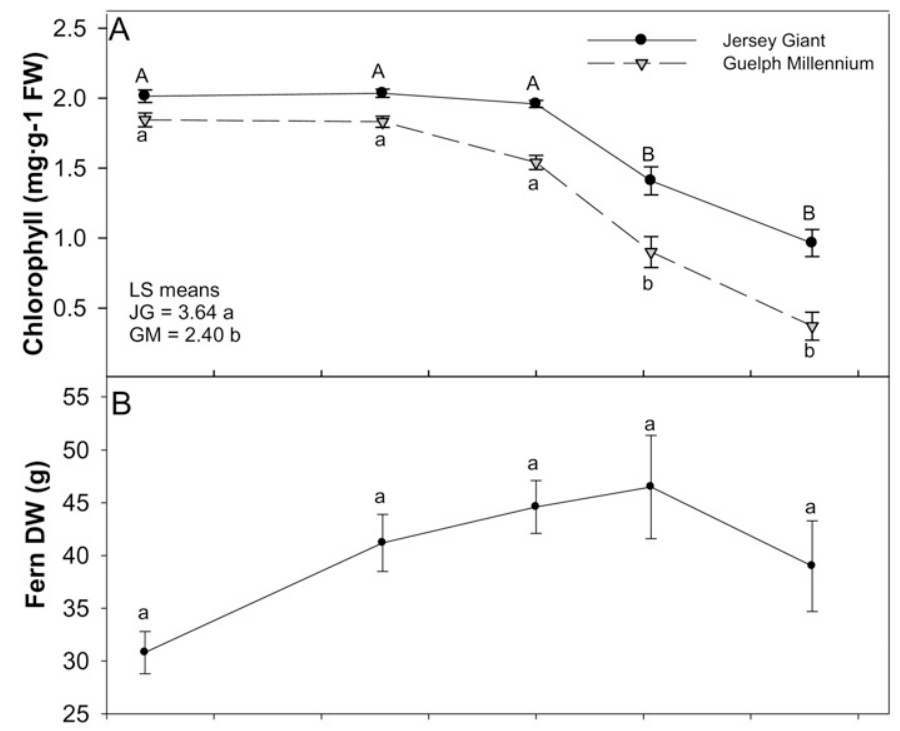

10 Aug. 24 Aug. 7 Sept. 21 Sept. 5 Oct. 19 Oct. 2 Nov. 16 Nov. Date

Fig. 3. (A) Fern chlorophyll concentrations for two asparagus cultivars, Jersey Giant (JG) and Guelph Millennium (GM), for five fall sampling dates. (B) Fern dry weight pooled across cultivars, years (2008 and 2009), and locations (two sites at the Simcoe Research Station, Simcoe, Ontario, Canada). For fern chlorophyll data, upper- and lower-case letters denote differences between sample dates within cultivar as determined by Tukey's honestly significant difference at $P \leq 0.05$. Vertical error bars represent the sE for each sampling date: fern chlorophyll $(\mathrm{n}=8)$ and fern dry weight $(\mathrm{n}=16)$; LS means $=$ least square means.

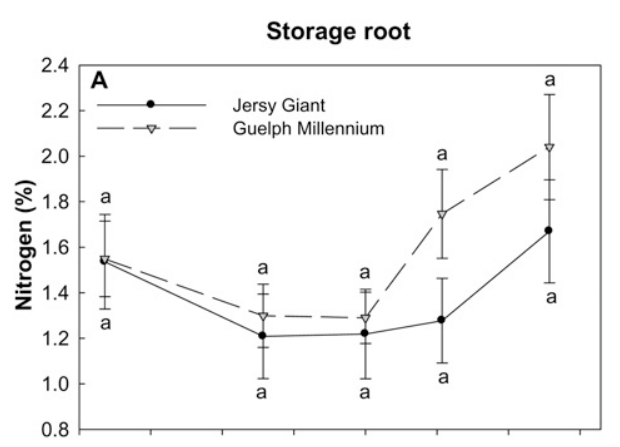

10 Aug. 24 Aug. 7 Sept. 21 Sept. 50

Date

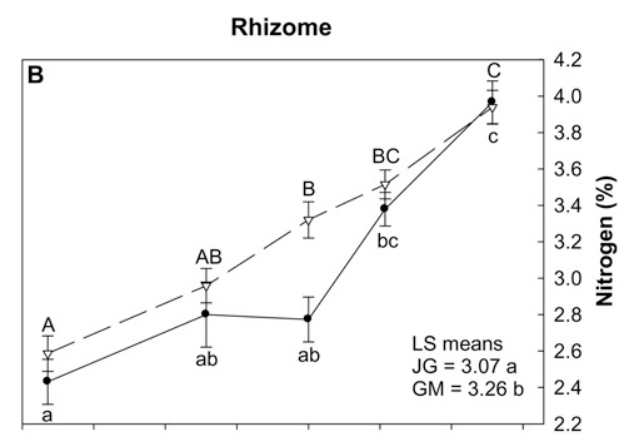

Date

Fig. 4. Nitrogen (\%) of (A) storage root and (B) rhizome tissue for two asparagus cultivars, Jersey Giant (JG) and Guelph Millennium (GM), over five fall sampling dates pooled across years (2008 and 2009) and locations (two sites at the Simcoe Research Station, Simcoe, Ontario, Canada). For rhizome nitrogen (\%) data, upper- and lower-case letters denote differences between sample dates within cultivar as determined by Tukey's honestly significant difference at $P \leq 0.05$. For storage root nitrogen (\%) data, both cultivars are shown although the effects of cultivar, sampling dates, and their interaction were not significant. Vertical error bars represent the SE at each sampling date $(\mathrm{n}=8)$; LS means $=$ least square means. 
with 2008. The first frost was also 1 week earlier in 2009 than in 2008. As a result, freezing injury to the cladophyll tissue of JG was observed in Nov. 2009 (Fig. 2A). At this same time, crowns of JG did not appear dormant compared with GM (Fig. 2B). Buds and young storage roots were growing actively (white in appearance) and fern was green in $\mathrm{JG}$, whereas a rare storage root was actively growing, buds were quiescent, and fern had abscised in GM.

Throughout the sampling period, chlorophyll concentration was consistently lower in GM than JG (Fig. 3A). Visible fern senescence was apparent by mid- and late October for GM and $\mathrm{JG}$, respectively. The asparagus fern senesced from bottom to top and from oldest to youngest frond in both cultivars. Fern DW was similar for both cultivars through the sampling period (Fig. 3B).

Storage root nitrogen (Fig. 4A) did not change significantly during the sampling period for both cultivars; however, it appeared to increase in the fall as chlorophyll concentration decreased (Fig. 3A); interestingly, GM appeared to have lower chlorophyll levels and higher nitrogen levels compared with JG. Rhizome nitrogen (Fig. 4B) increased through the fall for both cultivars but was higher in GM than JG in early October. Rhizome nitrogen was negatively correlated with chlorophyll concentration (GM: $r=-0.82, P<0.0001$; JG: $r=-0.71, P<$ 0.0001 ) and was present at twice the concentration observed for storage root tissue.

Dry MatTer AND Dehydration. Percent water content of storage root (Fig. 5A), rhizome (Fig. 5B), and whole crown (Fig. 5C) tissues decreased until mid-October. Rhizome and
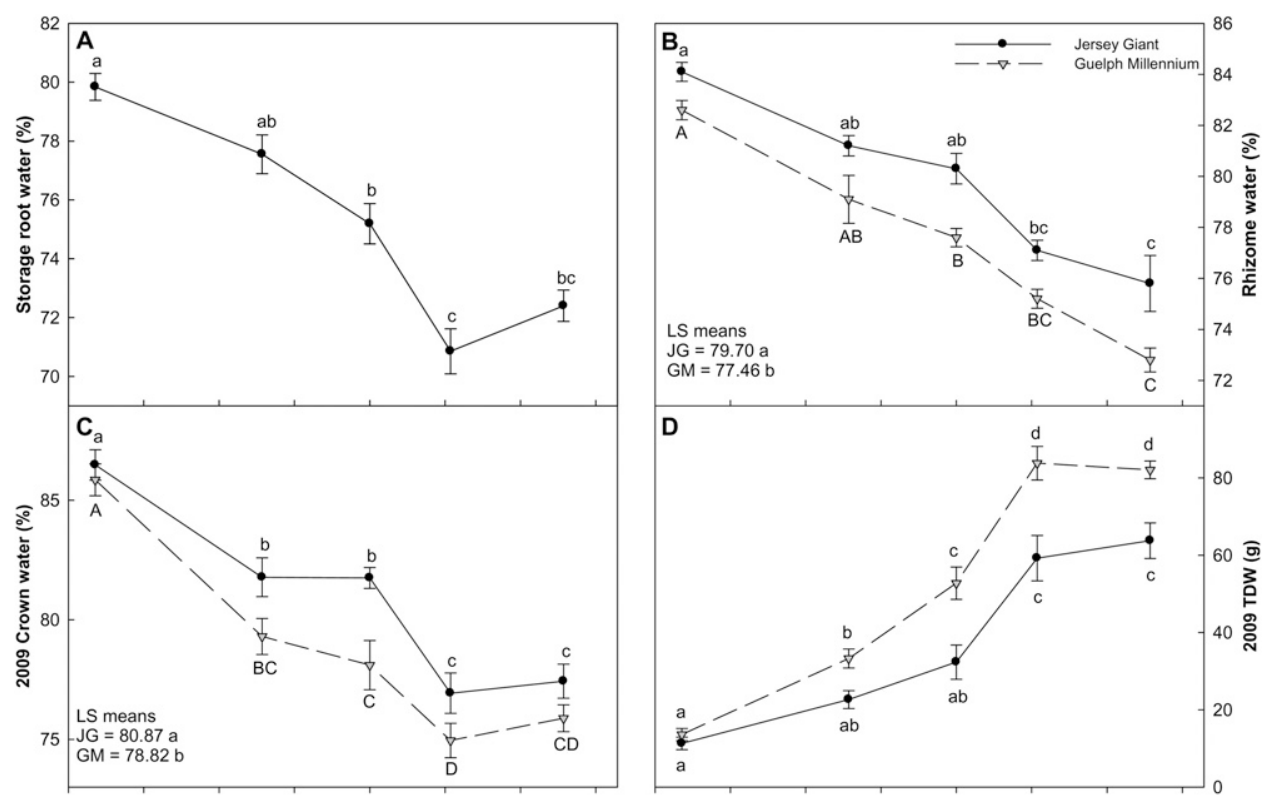

10 Aug. 24 Aug. 7 Sept. 21 Sept. 5 Oct. 19 Oct. 2 Nov. 16 Nov. 10 Aug. 24 Aug. 7 Sept. 21 Sept. 5 Oct. 19 Oct. 2 Nov. 16 Nov. Date

Date

Fig. 5. (A) Storage root water (\%), (B) rhizome water (\%), (C) crown water (\%), and (D) total crown dry weight (TDW) for two asparagus cultivars, Guelph Millennium (GM) and Jersey Giant (JG), over five fall sampling dates pooled across locations (two sites at the Simcoe Research Station, Simcoe, Ontario, Canada). Storage root and rhizome water (\%) are pooled across years (2008 and 2009); vertical error bars represent the SE at each sampling date $(\mathrm{n}=8)$. Storage root water $(\%)$ is pooled across cultivars. Only 2009 crown water (\%) and TDW are presented; vertical error bars represent the SE at each sampling date $(n=4)$. Upper- and lower-case letters indicate differences between sampling dates within cultivar for rhizome and crown water (\%). For TDW, letters indicate non-pairwise differences between cultivars and sample dates as determined by Tukey's honestly significant differences at $P \leq 0.05$; LS means $=$ least square means. whole crown percent water were consistently lower for GM as ompared with JG (Fig. 5B-C).

Crown dry weight was higher for GM compared with JG percent water (Fig. 5C); the two parameters were negatively correlated (GM: $r=-0.86, P<0.0001$; JG: $r=-0.81, P<$ $001)$. In addition, chlorophyll content was positively correstorage root: GM: $r=0.72, P=0.001 ; \mathrm{JG}: r=0.69, P=$ $-0.81, P<0.0001$; JG: $r=-0.65, P=0.005)$.

TOTAL NON-STRUCTURAL CARBOHYDRATES. Both GM and JG ollowed similar TNC partitioning trends throughout the fall. -structural carbohydrates (HNC) (Fig. 6B) increased from -August to mid-October. The concentration of storage root

Fig. 6C) did not change through the sampling period. from early October to November. The concentration of LNC Fig. 6D) for GM rhizome tissue increased from mid-October to (horember, whereas that for JG did not change; LNC for significant, HNC (Fig. 6E) of GM appeared to decline as LNC increased. The higher concentration in rhizome LNC (Fig. 6D) of GM explains the higher rhizome TNC in November as compared with that of JG (Fig. 6F). The concentration of rhizome HNC (Fig. 6E) was on average $60 \%$ lower than that of LNC (Fig. 6D) throughout the samplings.

Rhizome and storage roots differed not only for fall patterns of carbohydrate accumulation, but also for concentrations of these compounds. Rhizome tissue accumulated half as much HNC (Fig. 6E) as storage roots (Fig. 6B), resulting in the rhizome tissue having on average 25\% less TNC (Figs. 6C and F) throughout the sampling period.

Fructan. Both low-molecularweight fructan (LF) (Fig. 7) and high-molecular-weight fructan (HF) (Fig. 7B) increased from early $\mathrm{Au}-$ gust to early September within the storage roots. LF decreased, whereas HF did not change from early October to mid-November. Total fructan increased from mid-August to midSeptember and declined from midOctober to November (Fig. 7C); the decrease resulted from diminished LF concentration. Storage root HNC (Fig. 6B) and HF (Fig. 7B) concentrations were similar and did not vary 


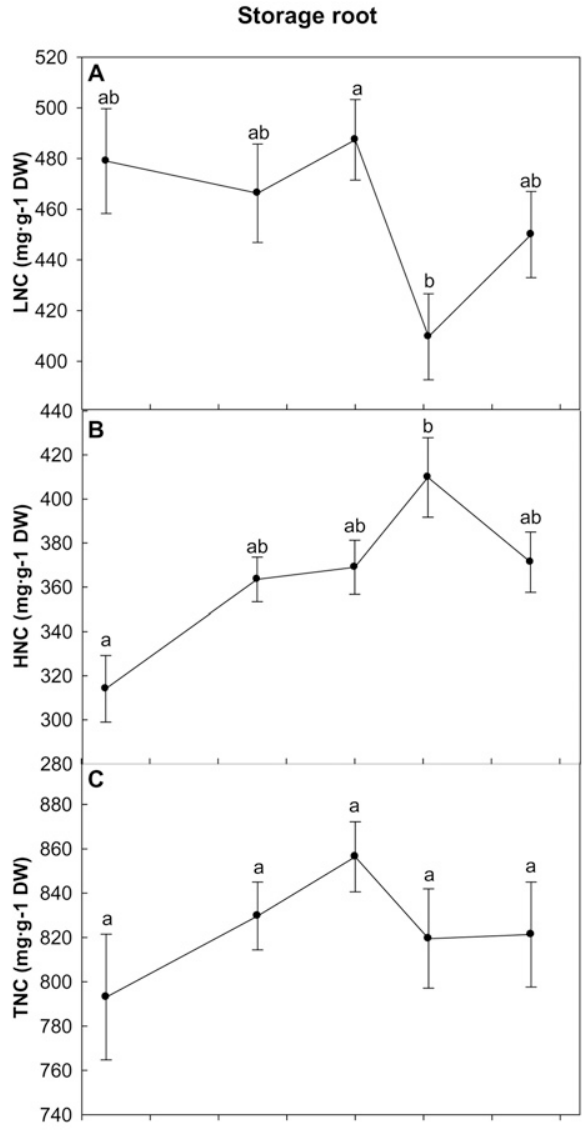

10 Aug. 24 Aug. 7 Sept. 21 Sept. 5 Oct. 19 Oct. 2 Nov. 16 Nov. Date

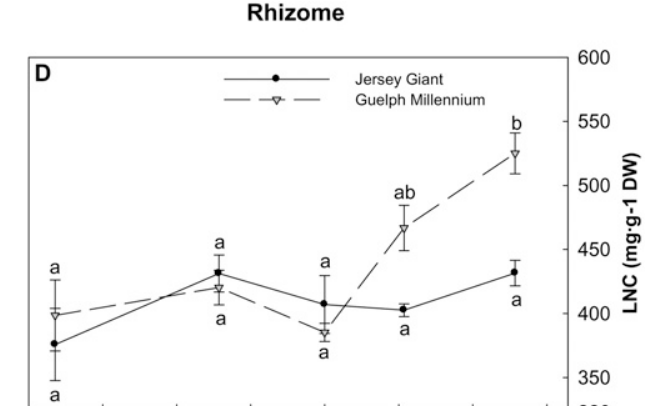

E

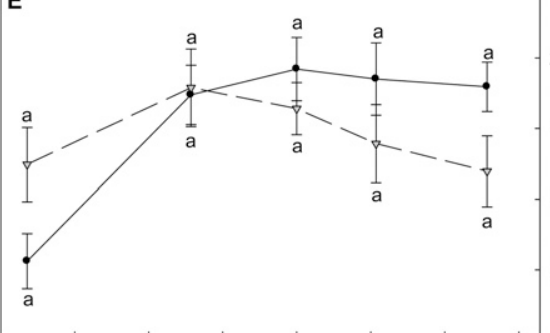

F

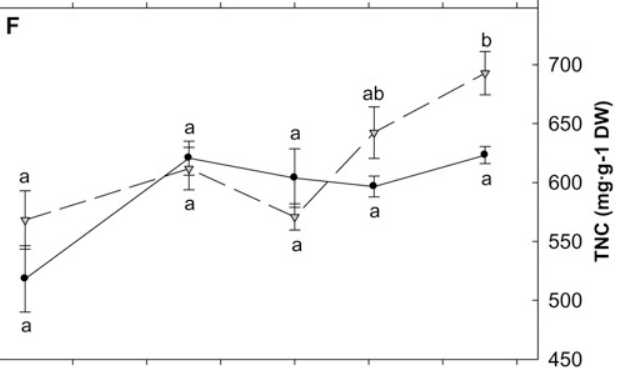

10 Aug. 24 Aug. 7 Sept. 21 Sept. 5 Oct. 19 Oct. 2 Nov. 16 Nov. Date

Fig. 6. Storage root (A) low-molecular-weight, non-structural carbohydrates (LNC), (B) high-molecular-weight, non-structural carbohydrates $(\mathrm{HNC})$, and $(\mathbf{C})$ total non-structural carbohydrate $(\mathrm{TNC}=\mathrm{LNC}+\mathrm{HNC})$ concentrations. Rhizome (D) LNC, (E) HNC, and (F) TNC concentrations are presented for two asparagus cultivars, Guelph Millennium and Jersey Giant. Storage root carbohydrate parameters were pooled across cultivars. Rhizome and storage root data are for five fall sampling dates pooled across years (2008 and 2009) and locations (two sites at the Simcoe Research Station, Simcoe, Ontario, Canada). Vertical error bars represent the SE at each sampling date for storage root $(n=16)$ and for rhizome $(n=8)$. Letters indicate differences between sampling dates for storage root carbohydrate parameters. Non-pairwise differences are shown using letters for rhizome LNC and TNC concentrations. Differences were determined by Tukey's honestly significant difference at $P \leq 0.05$. The effects of cultivar, sampling date, and their interactions were not significant for rhizome HNC and storage root TNC; however, both are shown separately.

by more than $5 \%$ during the sampling period. Storage root LF (Fig. 7A) concentrations accounted for $55 \%$ to $80 \%$ of the LNC (Fig. 6A) depending on sampling date.

Rhizome LF concentration did not change during the sampling period (Fig. 7D). HF concentration increased early in the fall and then did not change for JG; for GM, values were similar to those of JG from mid-August to mid-October, after which they decreased (Fig. 7E). Total rhizome fructan concentration increased from mid-August to mid-September and did not vary thereafter (Fig. 7F). The accumulation of total rhizome fructan could be explained by an increased concentration of HF during this period.

The concentration of rhizome HF (Fig. 7E) averaged 25\% lower than that of rhizome LF (Fig. 7B). Rhizome total fructan concentration (Fig. 7F) was from $60 \%$ to $75 \%$ of that present in storage root tissues (Fig. 7C). Furthermore, LF and HF (Fig. 7D-E) accounted for $55 \%$ to $65 \%$ of the LNC (Fig. 6D) and over $95 \%$ of the HNC (Fig. 6E), respectively, within rhizome tissue.
Simple sugars. Simple sugars (i.e., glucose, fructose, sucrose, and raffinose) were not distributed homogeneously throughout the asparagus crown and fluctuated across sampling dates (Fig. 8). Glucose and raffinose concentrations were too low to detect within storage root tissue (data not shown). Reducing sugars within rhizome tissue did not deviate from an average of 44 $\mathrm{mg} \cdot \mathrm{g}^{-1}$ DW throughout the sampling period (data not shown). Storage root reducing sugar (Fig. 8A) and sucrose (Fig. 8B) concentrations showed similar trends through the sampling period, decreasing from mid-August to mid-September and increasing from mid-October into November; however, only the decreasing reducing sugar concentration of GM in early fall and increasing reducing sugar and sucrose concentrations of GM in late fall were significant. The storage root tissue of GM had less reducing sugars in mid-September and higher sucrose concentrations through the sampling period than those observed for JG (Fig. 8A-B). Storage root LF concentration was negatively correlated with storage root reducing sugars (GM: $r=-0.57, P=$ 0.01 ; JG: $r=-0.63, P=0.015)$ and sucrose concentrations (GM: $r=$ $-0.89, P<0.0001 ; \mathrm{JG}: r=-0.70$, $P=0.002)$, which can explain the decline in total storage root fructan (Fig. 7C) but constant TNC (Fig. 6C) from mid-October into November.

Glucose concentrations of the rhizome increased from mid-August to mid-October and then did not change in both cultivars (Fig. 8C). Raffinose concentrations declined in both cultivars during October (Fig. 8D). Rhizome sucrose concentrations of both cultivars were similar and did not change from mid-August to mid-October; thereafter, concentration decreased for GM but did not change for JG (Fig. 8E). Glucose and raffinose concentrations were $\approx 10 \%$ of that for sucrose.

Proline AND PRotein. Storage root proline concentration increased from 1.77 and $2.23 \mathrm{mg} \cdot \mathrm{g}^{-1} \mathrm{DW}$ in mid-August to 16.68 and $12.46 \mathrm{mg} \cdot \mathrm{g}^{-1} \mathrm{DW}$ by November for GM and JG, respectively (Fig. 9A). In mid-November, GM had more proline than GM. Rhizome proline increased during the sampling period (Fig. 9B); however, cultivars did not differ (Table 1). Rhizome proline concentrations appeared to be $50 \%$ to $100 \%$ greater than values for storage roots on identical sampling dates.

Storage root protein concentrations increased for both cultivars during fall; however, GM and JG reached their maximum level in mid-October and mid-November, respectively (Fig. 9C), which is consistent with the earlier decline of chlorophyll concentration in GM than JG (Fig. 3A). Rhizome protein levels 

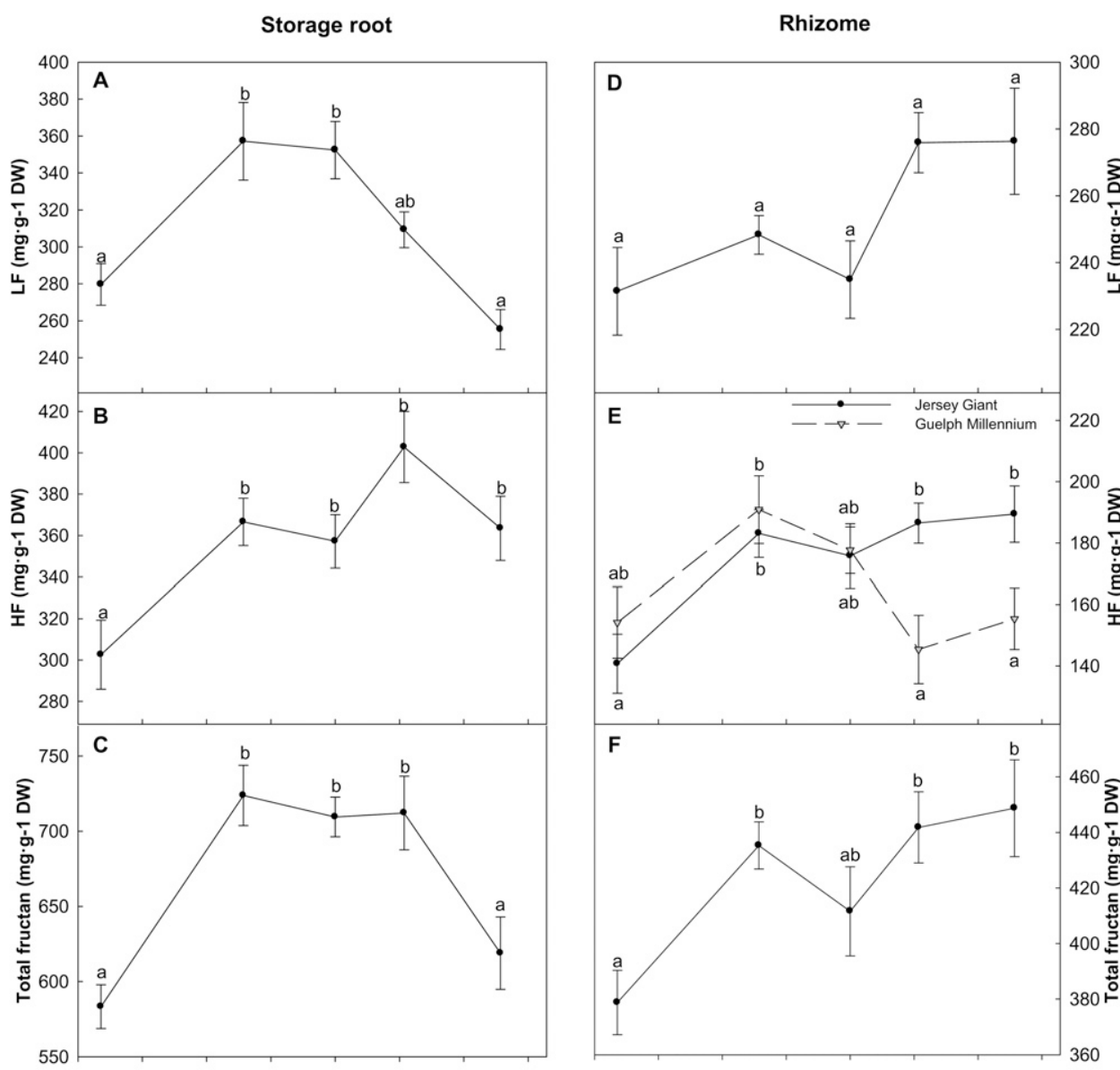

10 Aug. 24 Aug. 7 Sept. 21 Sept. 5 Oct. 19 Oct. 2 Nov. 16 Nov. 10 Aug. 24 Aug. 7 Sept. 21 Sept. 5 Oct. 19 Oct. 2 Nov. 16 Nov. Date

Date

Fig. 7. Storage root (A) low-molecular-weight fructan (LF), (B) high-molecular-weight fructan (HF), and (C) total fructan concentrations; rhizome (D) LF, (E) HF, and (F) total fructan concentrations across five fall sampling dates. For all parameters except HF, data were pooled across cultivars, years (2008 and 2009), and locations (two sites at Simcoe Research Station, Simcoe, Ontario, Canada). HF concentrations are presented separately for both cultivars. Letters distinguish different sampling dates or non-pairwise differences as determined by Tukey's honestly significant difference at $P \leq 0.05$. Vertical error bars represent the sE at each sampling date $(\mathrm{n}=16)$; rhizome HF $(\mathrm{n}=8)$.

did not vary during the fall for both cultivars; however, GM had more protein than JG (Fig. 9D).

StORAGE ROOT FREEZING TOLERANCE. Storage root $\mathrm{LT}_{50}$ values decreased by $-18{ }^{\circ} \mathrm{C}$ from mid-August into November for both cultivars (Fig. 10). Values were correlated with percent water (storage root: GM: $r=0.75, P=0.001$; JG: $r=0.79, P=$ 0.001, rhizome: GM: $r=0.93, P<0.0001$; JG: $r=0.79, P=$ 0.001 ) and proline concentration (storage root: GM: $r=-0.90$, $P<0.0001$; JG: $r=-0.69, P=0.002$, rhizome: GM: $r=-0.89$, $P<0.0001$; JG: $r=-0.77, P=0.003)$ as well as crown dry weight (GM: $r=-0.91, P<0.0001 ; \mathrm{JG}: r=-0.87, P<0.0001$ ) and chlorophyll concentration (GM: $r=0.87, P<0.0001$; JG: $r=0.76, P=0.001$ ). Storage root reducing sugar, protein, and nitrogen increased mainly during the latter part of fall, midOctober into November, resulting in non-significant correlations with $\mathrm{LT}_{50}$ over the entire sampling period.

\section{Discussion}

During fall, both cultivars varied similarly for a number of parameters (Table 2). Chlorophyll concentration of the fern, percent water of the crown, and storage root $\mathrm{LT}_{50}$ decreased, whereas crown dry weight, rhizome glucose, proline, and total fructan, and storage root $\mathrm{HF}, \mathrm{HNC}$, and protein increased. Cultivars differed consistently for several parameters. Over the sampling period, chlorophyll concentration and crown and rhizome percent water decreased earlier and were lower in GM than JG, whereas GM had more crown DW and rhizome protein than JG. Fall accumulation patterns for certain compounds differed between cultivars: rhizome HF decreased for GM and increased for JG; rhizome LNC and TNC and storage root sucrose increased and decreased, respectively, for GM, whereas values for JG did not change; storage root proline was greater in GM than JG late in the fall; and storage root proteins accumulated earlier in GM than JG.

Autumn fern SENESCence AND NITROGEN. Nitrogen within the storage root and rhizome tissues correlated negatively with chlorophyll concentration. This is supported by Ledgard et al. (1994) in which 90\% of the fern nitrogen was remobilized during fern senescence. Nitrogen reserves serve a metabolic role during early season growth of alfalfa, and storage before winter is crucial for winterhardiness and spring vigor (Dhont, 2006). Although storage root nitrogen and $\mathrm{LT}_{50}$ values were not correlated, nitrogen in the crown can be important for spring vigor because fern removal before senescence is detrimental to the following season's spear yield (Bai and Kelly, 1999). The lower, long-term yield observed for JG as compared with GM could be explained by inadequate crown nitrogen in JG that results from insufficient fern senescence and consequently remobilization. Low crown nitrogen may also weaken JG plants, increasing susceptibility to root diseases and consequently decline. In addition to crown carbohydrate content (Wilson et al., 2008), crown nitrogen should be considered when establishing metabolite associations with vigor and longevity in asparagus.

Dehydration AND Freezing tolerance. Cellular dehydration promotes a reduction in cellular volume and an increase in osmotic concentration, conferring resistance to endocytotic vesiculation (Steponkus, 1984) and intercellular ice crystal growth (Uemura et al., 2006). In this study, storage root tissues dehydrated before and to a greater extent than adjacent rhizome tissues and could explain why asparagus buds (Imakawa and Harada, 1989), like those of alfalfa (Haagenson et al., 2003), are generally less freezing-tolerant than adjacent overwintering 

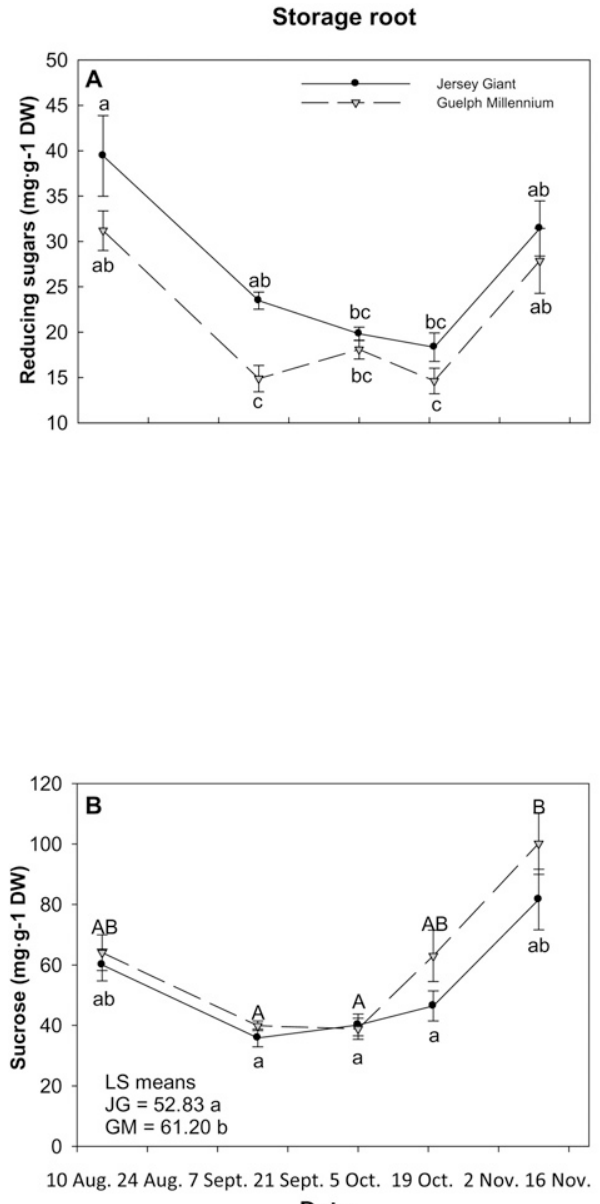

Date

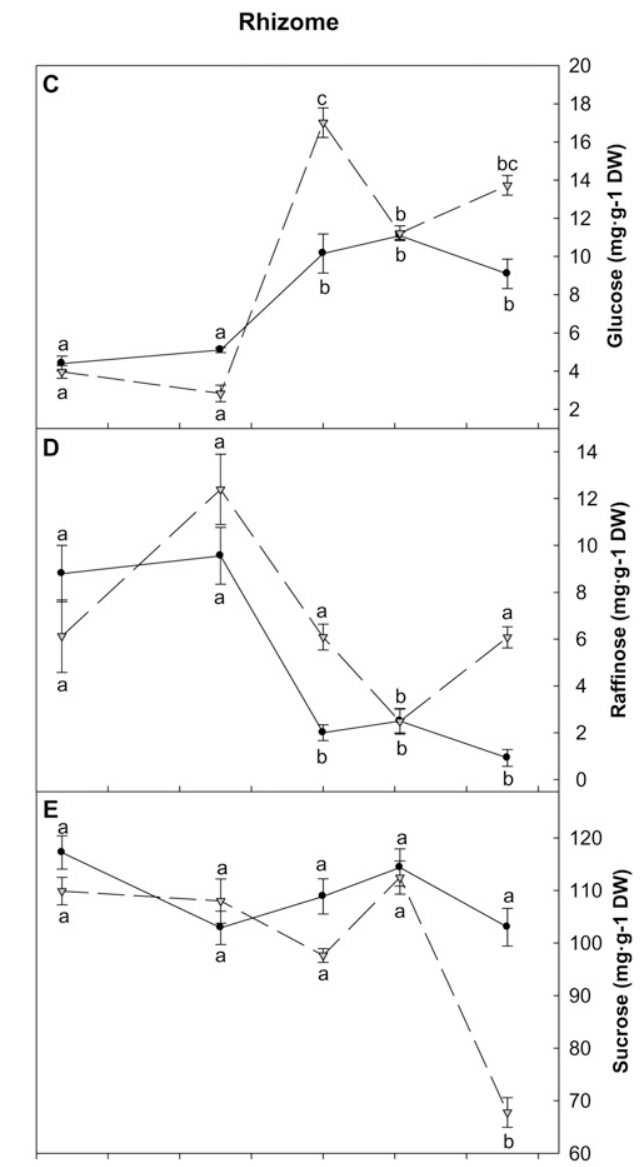

10 Aug. 24 Aug. 7 Sept. 21 Sept. 5 Oct. 19 Oct. 2 Nov. 16 Nov. Date

Fig. 8. Storage root (A) reducing sugar and (B) sucrose concentrations and rhizome (C) glucose, (D) raffinose, and (E) sucrose concentrations for the two asparagus cultivars, Guelph Millennium (GM) and Jersey Giant (JG), across five fall sampling dates and pooled across years (2008 and 2009) and locations (two sites at Simcoe Research Station, Simcoe, Ontario, Canada). Vertical error bars represent the sE at each sampling date $(\mathrm{n}=8)$. For storage root sucrose concentration data, upper- and lower-case letters denote differences between sample dates (within cultivar). Non-pairwise differences are denoted with letters for the remaining parameters $(n=16)$. Differences were determined by Tukey's honestly significant difference at $P \leq 0.05$; LS means $=$ least square means.

tissues. Although the storage root percent water content did not differ between cultivars, GM did have lower rhizome percent water than JG, supporting the hypothesis that GM would have superior crown freezing tolerance.

Storage roots acquired a high tolerance to freezing by the last sampling date in November when $\mathrm{LT}_{50}$ values for both cultivars were $\approx-19^{\circ} \mathrm{C}$. Cultivars did not differ for storage root freezing tolerance; however, one shortcoming of this study was an inability, as a result of technical difficulties, to measure $\mathrm{LT}_{50}$ as regrowth in whole crowns. This would have provided a true measure of winterhardiness of both storage roots and rhizomes. In southern Ontario, winter soil temperatures at $10 \mathrm{~cm}$ rarely fall below $-5^{\circ} \mathrm{C}$, even when the air temperature is below $-20^{\circ} \mathrm{C}$ (Simcoe Research Station, Simcoe, Ontario, Canada). Therefore, storage roots are likely winter hardy under local conditions. Further investigations into the rhizome, especially buds, could distinguish GM and JG because they not only differed for rhizome percent water but also rhizome protein, HF, sucrose, LNC, and TNC.

Crown CARbohydrates. Asparagus storage roots cycle carbohydrates annually (Haynes, 1987). During early spring and summer, carbohydrates, mainly in the form of simple sugars, are mobilized from the crown for spear and fern growth (Wilson et al., 2008). Once the fern matures,crown carbohydrates are replenished, mainly as fructan, and crown size increases until growth stops and the fern senesce. Carbohydrates accounted for over $80 \%$ of storage root dry weight throughout the fall sample period. Although the carbohydrate concentrations reported here are higher than those of Ernst and Krug (1998) and Pressman et al. (1989), they are similar to those from the field studies of Cairns (1992) and Haynes (1987). Fructan, in this study, was the main carbohydrate and explained $\approx 75 \%$ to $90 \%$ of the total carbohydrate throughout the sampling period.

As fern growth occurred between mid-August and mid-September, the storage root $\mathrm{HF}$ and LF increased, whereas the concentration of simple sugars decreased. Storage root LF declined in early October as crown dry weight increased and continued to decline into November as simple sugars increased. The interrelationship between fructan and simple sugars reported here for storage roots is consistent with previous studies in asparagus and other fructan-accumulating species (Cairns, 1992; Pressman et al., 1993; Van den Ende and Van Laere, 1996). Fern senescence could have resulted in the decline of storage root LF early in October through the limitation of carbohydrate import and consequently suppressed crown growth (Portes et al., 2008). The decline in substrate input would have restricted the LF synthesis, possibly leading to a net hydrolysis (Nelson and Spollen, 1987) as indicated by the relative increase in simple sugars.

Rhizome carbohydrate partitioning was distinctly different from that of storage roots and indicated that the transition from polymerization to hydrolysis could further signal the initiation of quiescence. From mid-October into November, rhizome tissue of GM showed a concomitant decline in $\mathrm{HF}$, an increase in LNC, and an increase in TNC, whereas the concentration of TNC for JG remained stable. The rhizome tissue carbohydrate profile of GM was more predictive of cold acclimation than that in JG. High LNC of GM would be advantageous for freezing tolerance because they are considered colligative cryoprotectants (Haagenson et al., 2003).

The abrupt decline in sucrose concentration for GM rhizome tissue between mid-October and early November compared with the stable concentration of JG was an interesting distinction between cultivars. Pressman et al. (1993) identified sucrose as a spring sprouting signal in asparagus. Ernst and Krug (1998) identified the absence of dormant bud starch to be a potential 


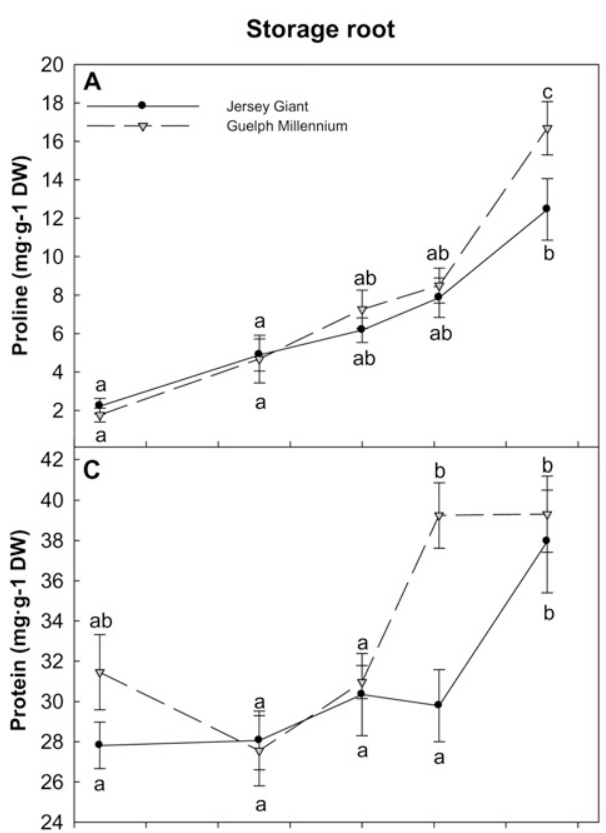

10 Aug. 24 Aug. 7 Sept. 21 Sept. 5 Oct. 19 Oct. 2 Nov. 16 Nov. Date

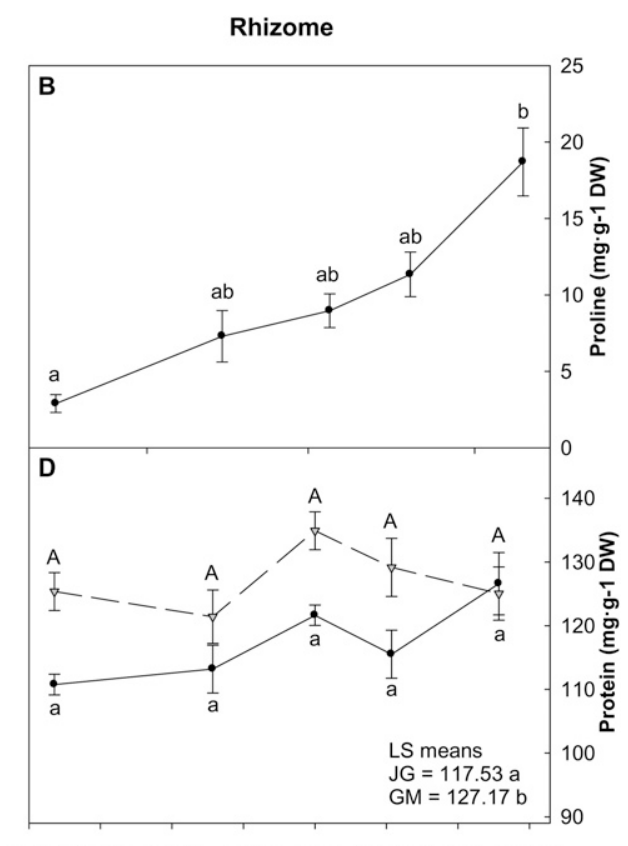

Date

Fig. 9. Proline and protein concentrations in storage root (A-B) and rhizome (C-D), respectively, for the two asparagus cultivars, Guelph Millennium (GM) and Jersey Giant (JG), across five fall sampling dates and pooled across years (2008 and 2009) and locations (two sites at the Simcoe Research Station, Simcoe, Ontario, Canada). Additionally, rhizome proline concentrations data were pooled across cultivars. Upper- and lower-case letters indicate differences between sampling dates within cultivar for rhizome protein concentrations. Non-pairwise differences are shown for storage root proline and protein concentrations. Differences were determined by Tukey's honestly significant difference at $P \leq 0.05$. Vertical error bars represent the sE at each sampling date for rhizome proline $(\mathrm{n}=16)$ and the remaining parameters $(\mathrm{n}=8)$; LS means = least square means.

observed in both Helianthus tuberosus, a fructan-accumulating species (Nelson and Spollen, 1987), and Solanum tuberosum, a starch-accumulating species (Coleman and King, 1984). In other species, however, high bud sucrose concentrations correlate with freezing tolerance (Palonen et al., 2000).

Sucrose is the primary transport sugar of asparagus (Cairns, 1992). The decline in sucrose concentration of GM rhizome tissue with fern senescence could be signaling the cessation of carbohydrate import into the crown. With further analysis, this characteristic reduction in rhizome sucrose content for GM could prove to be a strong indicator of the transition phase from growth to quiescence.

Proline. Proline often correlates with tolerance to cold (Patton et al., 2007b), but its role as a cryoprotectant has been contested (Xin and Browse, 2000). The concentrations of storage root and rhizome proline were highly correlated with storage root freezing tolerance in this study; however, proline accumulation was delayed until $\mathrm{LT}_{50}$ values decreased. Concentrations were associated with dehydration, which would be expected (Singh et al.,

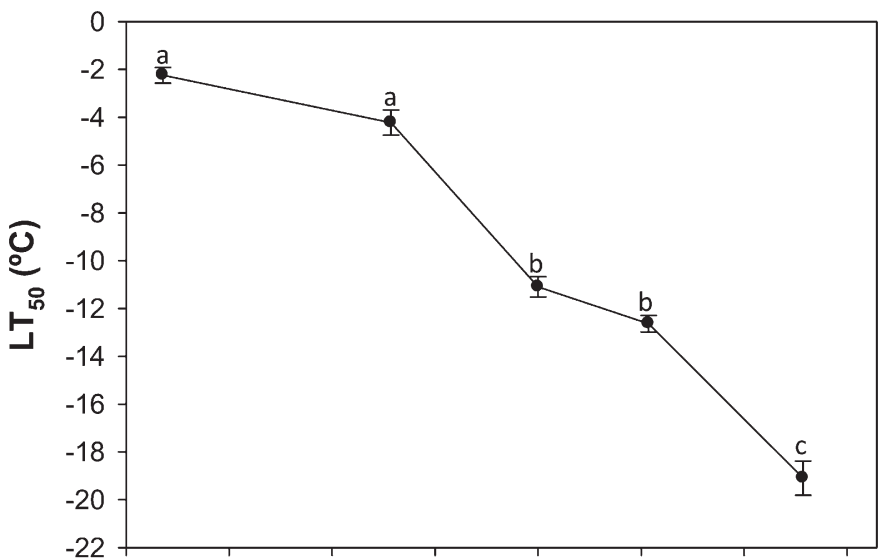

10 Aug. 24 Aug. 7 Sept. 21 Sept. 5 Oct. 19 Oct. 2 Nov. 16 Nov. Date

Fig. 10. Values representing the temperature at which $50 \%$ cell death occurs $\left(\mathrm{LT}_{50}\right)$, estimated as $50 \%$ ion leakage, for asparagus storage root tissue for five fall sampling dates pooled across cultivars (Guelph Millennium and Jersey Giant), years (2008 and 2009), and locations (two sites at Simcoe Research Station, Simcoe, Ontario, Canada). Letters distinguish significantly different sampling dates as determined by Tukey's honestly significant difference at $P \leq 0.05$. Vertical error bars represent the SE at each sampling date $(\mathrm{n}=16)$.

indicator of "sprouting ability." Starch synthesis of GM dormant buds may have resulted in the observed decline of rhizome sucrose. This would support the hypothesis and observation that GM was dormant before JG. Low sucrose and high polysaccharide concentrations of dormant meristems is also
1972; Tatar and Gevrek, 2008), although correlation coefficients were moderate. Proline accumulated through the fall in the rhizome tissue to a greater extent than within adjacent storage root tissue, although storage roots dehydrated to a greater extent than rhizome tissue. High rhizome proline content could be a direct consequence of dehydration (Lalk and Dorffling, 1985) or a result of proline (Fischer et al., 1998) or a pentose phosphate pathway precursor (Sarkar et al., 2009) transport during fern senescence.

Cultivars did not differ for proline concentration in the rhizome. If GM and JG do indeed have different levels of winterhardiness, and the physiological state of the rhizome is the primary determinant, then this compound may not be important to distinguish them. Alternatively, proline could be a metabolic reserve over winter (Sarkar et al., 2009) and into spring (Dhont et al., 2003). The biochemical connection between crown proline accumulation and abscisic acid (Pardossi et al., 1992), leaf senescence (Leopold, 1961), dormancy (Matsubara, 1980), and winterhardiness (Kalberer et al., 2007) requires further analysis.

Summary. This study suggests that cold acclimation of asparagus crowns can be categorized into three phenological phases. The first phase was characterized by the accumulation of osmotic constituents from August to September. The second phase began when fern senescence, fructan hydrolysis, dehydration, and crown growth occurred, because temperature and photoperiod decreased during October. The third phase occurred from mid-October into November, as rhizome nitrogen and storage root protein accumulated and signs of quiescence 
Table 2. Summary of changes during fall (mid-August to mid-November) for variables measured in two asparagus cultivars, Guelph Millennium (GM) and Jersey Giant (JG). ${ }^{\mathrm{z}}$

\begin{tabular}{|c|c|c|c|c|c|c|}
\hline Variable $^{\mathrm{y}}$ & No change & Increase & Decrease & $\begin{array}{l}\text { Increase then } \\
\text { decrease }\end{array}$ & $\begin{array}{l}\text { Decrease then } \\
\text { increase }\end{array}$ & Cultivar specificity \\
\hline Chlorophyll & & & $\mathrm{x}$ & & & GM less than JG \\
\hline Crown water $(\%)$ & & & $\mathrm{x}$ & & & GM less than JG \\
\hline Crown TDW & & $\mathrm{x}$ & & & & GM more than JG \\
\hline \multicolumn{7}{|l|}{ Rhizome } \\
\hline Glucose & & $\mathrm{x}$ & & & & \\
\hline $\mathrm{HF}$ & & & & & & GM decrease; JG increase \\
\hline $\mathrm{HNC}$ & $\mathrm{x}$ & & & & & \\
\hline LF & $\mathrm{x}$ & & & & & \\
\hline LNC & & & & & & GM increase; JG no change \\
\hline Proline & & $\mathrm{x}$ & & & & \\
\hline Total fructan & & $\mathrm{x}$ & & & & \\
\hline \multicolumn{7}{|l|}{ Storage root } \\
\hline Water $(\%)$ & & & $\mathrm{x}$ & & & \\
\hline $\mathrm{HF}$ & & $\mathrm{x}$ & & & & \\
\hline $\mathrm{HNC}$ & & $\mathrm{x}$ & & & & \\
\hline LF & & & & $\mathrm{x}$ & & \\
\hline LNC & & & $\mathrm{x}$ & & & \\
\hline Proline & & $\mathrm{x}$ & & & & GM greater than JG late in fall \\
\hline Protein & & $\mathrm{x}$ & & & & GM earlier than JG \\
\hline Reducing sugars & & & & & $\mathrm{x}$ & \\
\hline
\end{tabular}

${ }^{\mathrm{z}}$ Changes are generalized over the 3-month sampling period and highlight statistically significant differences.

${ }^{\mathrm{y}} \mathrm{DW}=$ dry weight; TDW = total dry weight; HF = high-molecular-weight fructan; HNC = high-molecular-weight, non-structural carbohydrate; $\mathrm{LF}=$ low-molecular-weight fructan; LNC = low-molecular-weight, non-structural carbohydrate; TNC = total non-structural carbohydrate; $\mathrm{LT}_{50}=$ value representing the temperature at which $50 \%$ cell death occurs, as measured by $50 \%$ ion leakage.

(dormancy traits) were present; i.e., dehydration, fern senescence, decreased rhizome sucrose concentration, increased storage root simple sugars, and the cessation of growth. Early fern senescence did not differentially influence storage root freezing tolerance, although the associated early nitrogen reclamation, high storage root proline concentration, and timely dormancy traits could be advantageous in locations with cold winters.

The hypothesis that early fern senescence in GM resulted in improved freezing tolerance compared with JG could not be definitively tested without $\mathrm{LT}_{50}$ data derived from whole-plant freezing studies. The $\mathrm{LT}_{50}$ observed in storage roots suggests these organs may not be prone to damage under normal conditions and further analyses should focus on the rhizome, which contains meristematic buds. The rhizome of GM had greater dehydration and LNC compared with JG; because these traits may be correlated with freezing tolerance, future analyses concentrating on rhizome freezing and physiology will prove crucial for investigations of asparagus winterhardiness, leading to identification of indirect selection parameters in breeding programs.

\section{Literature Cited}

Alden, J. and R. Hermann. 1971. Aspects of the cold-hardiness mechanism in plants. Bot. Rev. 37:37-142.

Allison, S., B. Chang, T. Randolph, and J. Carpenter. 1999. Hydrogen bonding between sugar and protein is responsible for inhibition of dehydration-induced protein unfolding. Arch. Biochem. Biophys. 365:289-298.

Ashworth, E., V. Stirm, and J. Volenec. 1993. Seasonal variations in soluble sugars and starch within woody stems of Cornus sericea L. Tree Physiol. 13:379-388.

Bai, Y. and J. Kelly. 1999. Pre-senescence removal of asparagus (Asparagus officinalis L.) fern. Acta Hort. 479:427-430.

Bradford, M. 1976. A rapid and sensitive method for the quantification of microgram quantities of protein utilizing the principle of proteindye binding. Anal. Biochem. 72:248-254.

Bressan, R., P. Hasegawa, and R. Locy. 2006. Stress physiology, p. 690-691. In: Taiz, L. and E. Zeiger (eds.). Plant physiology. 4th Ed. Sinauer, Sunderland, MA.

Burrows, R., L. Waters, and A. Markhart. 1989. Cold acclimation of asparagus seedlings subjected to low temperatures or water stress. HortScience 24:812-814. 
Caffrey, M., V. Fonseca, and C. Leopold. 1988. Lipid-sugar interactions. Plant Physiol. 86:754-758.

Cairns, A. 1992. A reconsideration of fructan biosynthesis in storage roots of Asparagus officinalis L. New Phytol. 120:463-473.

Coleman, W. and R. King. 1984. Changes in endogenous abscisic acid, soluble sugars and proline levels during tuber dormancy in Solanum tuberosum L. Amer. J. Potato Res. 61:437-449.

Dhont, C. 2006. Nitrogen reserves, spring regrowth and winter survival of field-grown alfalfa (Medicago sativa) defoliated in the autumn. Ann. Bot. (Lond.) 97:109-120.

Dhont, C., Y. Castonguay, P. Nadeau, G. Belanger, and F. Chalifour. 2003. Alfalfa root nitrogen reserves and regrowth potential in response to fall harvests. Crop Sci. 43:181-194.

Ernst, M. and H. Krug. 1998. Seasonal growth and development of asparagus (Asparagus officinalis L.). III. The effect of temperature and water stress on carbohydrate content in storage roots and rhizome buds. Gartenbauwissenschaft 63:202-208.

Fischer, W., B. Andre, D. Rentsch, S. Krolkiewicz, M. Tegeder, K. Breitkreuz, and W. Frommer. 1998. Amino acid transport in plants. Trends Plant Sci. 3:188-195.

Fritz, V., C. Rosen, W. Hutchison, R. Becker, J. Beckerman, J. Wright, C. Tong, and T. Nennich. 2005. Growing asparagus in Minnesota: A production guide. 14 Feb. 2011. <http://www.extension.umn.edu/ distribution/horticulture/DG1861.html/>.

Gasecka, M., J. Stachowiak, W. Krzesinski, M. Knaflewski, and P. Golinski. 2008. Changes in glucose, fructose and sucrose contents in storage roots of asparagus during vegetation period. Veg. Crops Res. Bul. 69:145-154.

Grotelueschen, R. and D. Smith. 1968. Carbohydrates in grasses. III. Estimation of the degree of polymerization of the fructosans in the stem bases of timothy and bromegrass near seed maturity. Crop Sci. $8: 210-212$.

Guo, J., W. Jermyn, and M. Turnbull. 2002. Diurnal and seasonal photosynthesis in two asparagus cultivars with contrasting yield. Crop Sci. 42:399-405.

Guy, C. 2003. Freezing tolerance of plants: Current understanding and selected emerging concepts. Can. J. Bot. 81:1216-1223.

Haagenson, D., S. Cunningham, and J. Volenec. 2003. Root physiology of less fall dormant, winter hardy alfalfa selections. Crop Sci. 43:1441-1447.

Hartung, A. and C. Stephens. 1983. Effects of allelopathic substances produced by asparagus on incidence and severity of asparagus decline due to Fusarium crown rot. J. Chem. Ecol. 9:1163-1174.

Haynes, R. 1987. Accumulation of dry matter and changes in storage carbohydrate and amino acid content in the first two years of asparagus growth. Sci. Hort. 32:17-23.

Heber, U., L. Tyankova, and K. Santarius. 1971. Stabilization and inactivation of biological membranes during freezing in the presence of amino acids. Biochim. Biophys. Acta 241:578-592.

Hincha, D., D. Livingston, III, R. Premakumar, E. Zuther, N. Obel, C. Cacela, and A. Heyer. 2007. Fructans from oat and rye: Composition and effects on membrane stability during drying. Biochim. Biophys. Acta 1768:1611-1619.

Imakawa, S. and T. Harada. 1989. Freezing resistance of juvenile plants of asparagus (Asparagus officinalis L.). J. Fac. Agr. Hokkaido Univ. 64:70-74.

Kacperska-Palacz, A. 1978. Physiological mechanisms of frost tolerance in plants. Acta Hort. 81:23-35.

Kalberer, S., R. Arora, N. Leyva-Estrada, and S. Krebs. 2007. Cold hardiness of floral buds of deciduous azaleas: Dehardening, rehardening and endodormancy in late winter. J. Amer. Soc. Hort. Sci. 132:73-79.

Krug, H. 1999. Seasonal growth and development of asparagus (Asparagus officinalis L.). V. Fern 'ripening' and crown activity in open fields. Gartenbauwissenschaft 64:165-172.

Lalk, I. and K. Dorffling. 1985. Hardening, abscisic acid, proline and freezing resistance in two winter wheat varieties. Physiol. Plant. 63:287-292.
Ledgard, S., J. Douglas, M. Sprosen, and J. Follett. 1994. Uptake and redistribution of $15 \mathrm{~N}$ within an established asparagus crop after application of $15 \mathrm{~N}$-labelled nitrogen fertilizer. Ann. Bot. (Lond.) 73:169-173.

Leopold, A. 1961. Senescence in plant development. Science 134: 1727-1732.

Levitt, J. 1980. Responses of plants to environmental stresses: Chilling, freezing, and high temperature stress. 2nd Ed. Academic Press, New York, NY.

Lichtenthaler, H. 1987. Chlorophylls and carotenoids: Pigments of photosynthetic biomembranes. Methods Enzymol. 148:350-377.

Livingston, D., III. 1990. Fructan precipitation from a water/ethanol extract of oats and barley. Plant Physiol. 92:767-769.

Livingston, D., III. 1996. The second phase of cold hardening: Freezing tolerance and fructan isomer changes in winter cereal crowns. Crop Sci. 36:1568-1573.

Matsubara, S. 1980. ABA content and levels of GA like substances in asparagus buds and roots in relation to bud dormancy and growth. J. Amer. Soc. Hort. Sci. 105:527-532.

McCleary, B., S. Charnock, P. Rossiter, M. O'Shea, A. Power, and R. Lloyd. 2006. Measurement of carbohydrates in grain, feed and food. J. Sci. Food Agr. 86:1648-1661.

McCleary, B., A. Murphy, and D. Mugford. 1997. Determination of oligofructans and fructan polysaccharides in foodstuffs by an enzymatic/spectrophotometric method: Collaborative study. J. AOAC Intl. 83:356-364.

Nelson, C. and W. Spollen. 1987. Fructans. Physiol. Plant. 71:512-516. Norio, S., B. Noureddine, O. Shuichi, and O. Mitsuru. 2007. The metabolism of the fructooligosaccharides in asparagus (Asparagus officinalis L.), p. 231-230. In: Norio, S., B. Noureddine, and O. Shuichi (eds.). Recent advances in fructooligosaccharides research. Research Singpost, Kerala, India.

Palonen, P., D. Buszard, and D. Donnelly. 2000. Changes in carbohydrates and freezing tolerance during cold acclimation of red raspberry cultivars grown in vitro and in vivo. Physiol. Plant. 110: 393-401.

Pardossi, A., P. Vernieri, and F. Tognoni. 1992. Involvement of abscisic acid in regulating water status in Phaseolus vulgaris L. during chilling. Plant Physiol. 100:1243-1250.

Patton, A., S. Cunningham, J. Volenec, and Z. Reicher. 2007a. Differences in freeze tolerance of zoyiagrasses: I. Role of proteins. Crop Sci. 47:2162-2169.

Patton, A., S. Cunningham, J. Volenec, and Z. Reicher. 2007b. Differences in freeze tolerance of zoyiagrasses: II. Carbohydrate and proline accumulation. Crop Sci. 47:2170-2181.

Patton, A. and Z. Reicher. 2007. Zoysiagrass species and genotypes differ in their winter injury and freeze tolerance. Crop Sci. 47:1619-1627.

Portes, M., R. Cassia, L. Figueiredo-Ribeiro, M. Angela, and M. de Carvalho. 2008. Low temperature and defoliation affect fructanmetabolizing enzymes in different regions of the rhizophores of Vernonia herbacea. J. Plant Physiol. 165:1572-1581.

Pressman, E., A. Schaffer, D. Compton, and E. Zamski. 1989. The effect of low temperature and drought on the carbohydrate content of asparagus. Plant Physiol. 134:209-213.

Pressman, E., A. Schaffer, D. Compton, and E. Zamski. 1993. Seasonal changes in the carbohydrate content of two cultivars of asparagus. Sci. Hort. 53:149-155.

Sakai, A. and W. Larcher. 1987. Frost survival of plants: Responses and adaptation to freezing stress. Springer-Verlag, New York, NY.

Sarkar, D., P. Bhowmik, Y. Kwon, and K. Shetty. 2009. Cold acclimation responses of three cool-season turfgrasses and the role of proline-associated pentose phosphate pathway. J. Amer. Soc. Hort. Sci. 134:210-220.

Shelton, D. and M. Lacy. 1980. Effect of harvest duration on yield and on depletion of storage carbohydrates in asparagus roots. J. Amer. Soc. Hort. Sci. 105:332-335.

Shiomi, N. 1992. Content of carbohydrate and activities of fructosyltransferase and invertase in asparagus roots during the 
fructo-oligosaccharide- and fructo-polysaccharide-accumulating season. New Phytol. 122:421-432.

Singh, T., L. Paleg, and D. Aspinall. 1972. Nitrogen metabolism and growth in the barley plant during water stress. Aust. J. Biol. Sci. 26:45-56.

Steponkus, P. 1984. Role of the plasma membrane in freezing injury and cold acclimation. Annu. Rev. Plant Physiol. 35:543-584.

Stout, D. 1980. Alfalfa water status and cold hardiness as influenced by cold acclimation and water stress. Plant Cell Environ. 3:237-241.

Taga, T., H. Iwabuchi, and K. Yamabuki. 1980. Analysis of cultivation environments on the growth of asparagus. I. Effect of harvesting term on the yield and the carbohydrate in the stock root. Bul. Hokkaido Prefect. Agr. Expt. Sta. 43:63-71.

Tanino, K., C. Weiser, L. Fuchigami, and T. Chen. 1990. Water content during abscisic acid induced freezing tolerance in bromegrass cells. Plant Physiol. 93:460-464.

Tatar, O. and M. Gevrek. 2008. Influence of water stress on proline accumulation, lipid peroxidation and water content of wheat. Asian J. Plant Sci. 7:409-412.

Thebud, R. and K. Santarius. 1982. Effects of high-temperature stress on various biomembranes of leaf cells in situ and in vitro. Plant Physiol. 70:200-205.

Thomas, H. and J. Stoddart. 1980. Leaf senescence. Annu. Rev. Plant Physiol. 31:83-111.

Trischuk, R., B. Schilling, M. Wisniewski, and L. Gusta. 2006. Freezing stress: Systems biology to study cold tolerance, p. 131155. In: Rao, K.V.M., A.S. Raghavendra, and K.J. Reddy (eds.).
Physiology and molecular biology of stress tolerance in plants. Springer, Dordrecht, The Netherlands.

Uemura, M., Y. Tominaga, C. Nakagawara, S. Shigematsu, A. Minami, and Y. Kawamura. 2006. Responses of the plasma membrane to low temperatures. Physiol. Plant. 126:81-89.

Van den Ende, W. and A. Van Laere. 1996. De-novo synthesis of fructans from sucrose in vitro by a combination of two purified enzymes (sucrose:sucrose 1-fructosyltransferase and fructan:fructan 1-fructosyltransferase) from chicory roots (Cichorium intybus L.). Planta 200:335-342.

Wilson, D., S. Sinton, R. Butler, D. Drost, P. Paschold, G. Kruistum, J. Poll, C. Garcin, R. Pertierra, I. Vidal, and K. Green. 2008. Carbohydrates and yield physiology of asparagus: A global overview. Acta Hort. 776:411-425.

Wooley, D., A. Hughes, and M. Nichols. 1999. Carbohydrate storage and remobilization in asparagus: Studies using dry weight changes, C-14 and high pressure liquid chromatography. Acta Hort. 415:201207.

Woolley, D., D. Karno, and M. Nichols. 2002. Effects of day length on dry matter partitioning in asparagus. Acta Hort. 589:243-247.

Xin, Z. and J. Browse. 2000. Cold comfort farm: The acclimation of plants to freezing temperatures. Plant Cell Environ. 23:893-902.

Yemm, E. and A. Willis. 1954. The estimation of carbohydrates in plant extracts by anthrone. Biochem. J. 57:508-514.

Zatylny, A., J. Proctor, and J. Sullivan. 1996. Assessing cold hardiness of red raspberry genotypes in the laboratory and field. J. Amer. Soc. Hort. Sci. 121:495-500. 